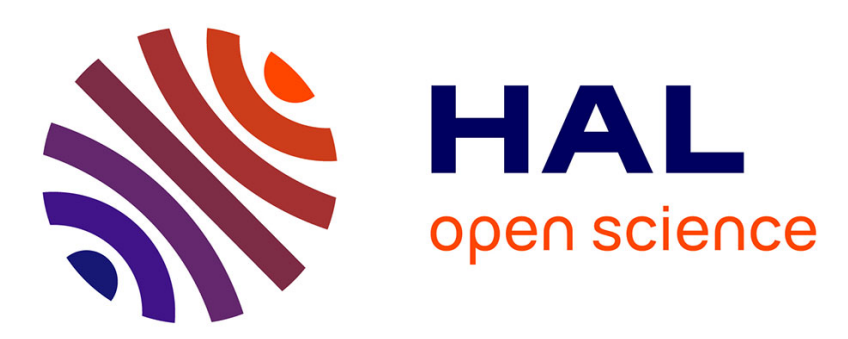

\title{
A novel immunomodulatory mechanism of ribavirin in suppressing natural killer cell function
}

Henry Ogbomo, Martin Michaelis, Behric Altenbrandt, Hans Wilhelm Doerr, Jindrich Cinatl

\section{- To cite this version:}

Henry Ogbomo, Martin Michaelis, Behric Altenbrandt, Hans Wilhelm Doerr, Jindrich Cinatl. A novel immunomodulatory mechanism of ribavirin in suppressing natural killer cell function. Biochemical Pharmacology, 2009, 79 (2), pp.188. 10.1016/j.bcp.2009.07.026 . hal-00535820

\author{
HAL Id: hal-00535820 \\ https://hal.science/hal-00535820
}

Submitted on 13 Nov 2010

HAL is a multi-disciplinary open access archive for the deposit and dissemination of scientific research documents, whether they are published or not. The documents may come from teaching and research institutions in France or abroad, or from public or private research centers.
L'archive ouverte pluridisciplinaire HAL, est destinée au dépôt et à la diffusion de documents scientifiques de niveau recherche, publiés ou non, émanant des établissements d'enseignement et de recherche français ou étrangers, des laboratoires publics ou privés. 


\section{Accepted Manuscript}

Title: A novel immunomodulatory mechanism of ribavirin in suppressing natural killer cell function

Authors: Henry Ogbomo, Martin Michaelis, Behric

Altenbrandt, Hans Wilhelm Doerr, Jindrich Cinatl Jr

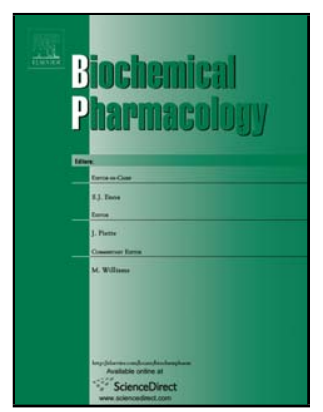

PII:

S0006-2952(09)00679-0

DOI:

doi:10.1016/j.bcp.2009.07.026

Reference:

BCP 10283

To appear in: $\quad B C P$

Received date: $\quad 9-6-2009$

Revised date: $\quad 30-7-2009$

Accepted date: $\quad 31-7-2009$

Please cite this article as: Ogbomo H, Michaelis M, Altenbrandt B, Doerr HW, Cinatl $\mathrm{Jr} \mathrm{J}$, A novel immunomodulatory mechanism of ribavirin in suppressing natural killer cell function, Biochemical Pharmacology (2008), doi:10.1016/j.bcp.2009.07.026

This is a PDF file of an unedited manuscript that has been accepted for publication. As a service to our customers we are providing this early version of the manuscript. The manuscript will undergo copyediting, typesetting, and review of the resulting proof before it is published in its final form. Please note that during the production process errors may be discovered which could affect the content, and all legal disclaimers that apply to the journal pertain. 
A novel immunomodulatory mechanism of ribavirin in suppressing natural killer cell

\section{function}

Henry Ogbomo, Martin Michaelis, Behric Altenbrandt, Hans Wilhelm Doerr, Jindrich Cinatl Jr.*

Institut für Medizinische Virologie, Klinikum der Johann Wolfgang Goethe-Universität, PaulEhrlich-Str. 40, 60596 Frankfurt am Main, Germany.

*Corresponding author: Jindrich Cinatl Jr., Institut für Medizinische Virologie, Klinikum der Johann Wolfgang Goethe-Universität, Paul-Ehrlich-Str. 40, 60596 Frankfurt am Main, Germany. Phone: 0049696301 6409, Fax: 00496963014302

E-mail: Cinatl@em.uni-frankfurt.de.

1 Page 1 of 40 


\section{ABSTRACT}

Ribavirin, a broad-spectrum anti-viral drug, exhibits immunomodulatory activities. To study direct effects of ribavirin on natural killer (NK) cell effector functions and signaling, resting NK cells and interleukin (IL)-15-activated NK cells were treated for 5 days with therapeutic ribavirin concentrations ranging from $5 \mu \mathrm{g} / \mathrm{ml}$ to $20 \mu \mathrm{g} / \mathrm{ml}$. Both resting and IL-15-activated NK cells that were not treated with ribavirin were used as control. Cytotoxicity assays, flow cytometry, enzyme linked immunosorbent assays, and western blot experiments were performed to elucidate ribavirin effect on NK cells. Results showed that ribavirin (not toxic at concentrations tested; $\mathrm{IC}_{50}>80 \mu \mathrm{g} / \mathrm{ml}$ ) had no influence on lysis of target cells by freshly isolated NK cells. Conversely, ribavirin dose-dependently inhibited lysis of target cells by up to $66 \%$ and impaired interferon gamma production when IL-15-activated NK cells were used. IL-15-induced increased expression and hence function of NK cell activating receptors including NKp30, NKp44, NKp46 and NKG2D were selectively down-regulated and impaired. These inhibitory effects were associated with the down-regulation of IL-15 receptor beta and gamma expression. Accordingly, downstream events involved in NK cell signaling via IL-15 receptors including the activation of Janus kinase (Jak)-1, signal transducer and activator of transcription STAT-1, STAT-3, and STAT-5 as well as pathways responsible for NK cell degranulation including extracellular signal-regulated kinase (ERK1/2) and c-Jun Nterminal kinase (JNK) were impaired. These results reveal a novel mechanism by which ribavirin exerts its immunomodulatory activities.

Keywords: NK cell activating receptors; NK cell signaling; NK cell degranulation; Perforin and granzyme B release; IL-15 receptors 


\section{INTRODUCTION}

Ribavirin (1- $\beta$-D-ribofuranosyl-1,2,4-triazole-3-carboxamide), a synthetic nucleoside analog, is a broad-spectrum inhibitor of RNA and DNA viruses that is currently licensed for the treatment of severe respiratory syncytial virus (RSV) disease [1] and chronic hepatitis C virus $(\mathrm{HCV})$ infection $[2,3]$. Antiviral properties of ribavirin were ascribed to inhibition of inosine monophosphate dehydrogenase, interference with viral RNA capping reactions; inhibition of viral polymerase and induction of error catastrophe resulting from the accumulation of lethal mutations in viral genome [4].

Apart from direct antiviral effects, ribavirin was reported to have immunomodulatory effects on different constituents of the immune system. Ribavirin induced a switch in T-helper (Th) cell phenotype from type 2 to type 1 [5]. In patients with chronic HCV infection, ribavirin was shown to exert anti-inflammatory effect by reducing the blood levels of interferon (IFN)- $\gamma$ and the expression of IFN- $\gamma$ by activated $\mathrm{T}$ cells [6], thus thereby helping to suppress IFN- $\gamma$-driven $\mathrm{T}$ cell activation and liver damage [6]. In macrophages, ribavirin inhibited the induction of pro-inflammatory cytokines like interleukin (IL)-1 $\beta$ and tumor necrosis factor (TNF)- $\alpha$ [7]. In dendritic cells, ribavirin suppressed the production of TNF- $\alpha$, IL-10, and IL-12(p70) [8]. In murine natural killer (NK) cells, ribavirin inhibited IFN- $\gamma$ production in a dose-dependent manner [9].

NK cells provide the first line of defense and substantially contribute to the elimination of virus-infected cells as well as antitumor immune response [10]. Moreover, IL15 is known to play a pivotal role in NK cell development in vivo as well as in NK cell activation and proliferation and is secreted in response to infectious pathogens to mediate NK cytotoxicity [11]. IL-15 and IL-2 receptor gamma (IL-2R $\gamma$ ) genes, both involved in lymphocyte activation and signaling, were reported to be down-regulated by ribavirin in RSVinfected human A549 pulmonary type II epithelial cells [12]. In NK cells, the IL-15 receptor includes IL-15R $\alpha$, IL-2/15R $\beta$ and $\gamma$ chain subunits ( $\beta$ and $\gamma_{c}$ subunits are shared with IL-2) 
[11]. As IL-2 and IL-15 share common signaling components, most evidence suggests that the interaction of IL-2 or IL-15 with their respective receptor complex in various cell types leads to a series of similar if not identical signaling events [13]. IL-15R $\beta$ is associated with Janus kinase (Jak)-1 and the $\gamma_{\mathrm{c}}$ is associated with Jak-3, resulting in signal transducer and activator of transcription (STAT)-3 and STAT-5 phosphorylation respectively, following ligation with IL-15 [13]. IL-15 also activates the phosphorylation of STAT-1 [14, 15]. In addition to signaling via IL-15/IL-15R, NK cell activation is also tightly regulated by a delicate balance between signaling through inhibitory [killer immunoglobulin-like receptors (KIR), CD94-NK group 2, member A (NKG2A)] and activating receptors [natural cytotoxic receptors (NCRsNKp30, NKp44 and NKp46), NK group 2, member D (NKG2D) and DNAX accessory molecule-1 (DNAM-1)] [10]. The expressions of these receptors are up-regulated upon treatment with IL-15 [16, 17]. Inhibitory receptors consist of a single polypeptide containing cytoplasmic immunoreceptor tyrosine-based inhibitory motifs that recruit tyrosine phosphatases and abort signaling. On the other hand, activating receptors typically couple to signaling adaptors that contain either an immunoreceptor tyrosine-based activating motif (ITAM, such as DAP12, FcR $\gamma$ or CD3 $\zeta$ ) or 'YXNM' motif, where ' $\mathrm{X}$ ' is any amino acid (such as the signaling adaptor DAP10) through interactions specified by their transmembrane regions [18]. Interestingly, signaling through DAP10, an adaptor that transmits important signals for NKG2D [19], was shown to be coupled to IL-15R signaling pathway [20]. Here, DAP10 was shown to specifically bind $\beta$ - and $\gamma$-chains of IL15R [20].

In this report, we have studied the direct effect of ribavirin on effector functions (including cytolytic activity and IFN- $\gamma$ production) of IL-15-activated human NK cells as well as molecular mechanisms by which ribavirin influence NK cell functions. We observed that ribavirin exerts immunomodulatory activities on NK cells by down-regulating the expression of IL-15R $\beta$ and $\gamma$ and thus inhibiting downstream events involved in NK cell signaling (IL- 
15-activation of Jak/STAT pathway) and degranulation [extracellular signal-regulated kinase

1

2 


\section{MATERIALS AND METHODS}

\subsection{Reagents and monoclonal antibodies}

Ribavirin (Virazole $®$ ) was obtained from Valeant Pharmaceuticals Germany GmbH

(Eschborn, Germany), DETA NONO-ate and tetrahydrobiopterin were purchased from Sigma-Aldrich (Taufkirchen, Germany), recombinant human IL-15 was from Cell Concepts (Umkirch, Germany). The following phycoerythrin (PE)-conjugated anti-human monoclonal antibodies (mAbs) were used: NKp30, NKp44, NKp46, NKG2D, DNAM-1, KIR-

KIR2DL2/DL3 and KIR3DL1, all from Miltenyi Biotec (Bergisch Gladbach, Germany), NKG2A, IL-2R $\beta$ and IL-2R $\gamma$ were from R\&D systems (Wiesbaden, Germany), perforin and granzyme B were from Abcam (Cambridge, UK). Unconjugated IL-15R $\alpha$ was from R\&D systems (Wiesbaden, Germany). Fluorescein isothiocynate (FITC)-conjugated lymphocyte function antigen (LFA)-1 was from BD Pharmingen (San Diego, CA, USA). For redirected killing experiments, purified NKp30, NKp44, NKp46, NKG2D, DNAM-1 mAb (Miltenyi Biotec, Bergisch Gladbach, Germany) were used.

\subsection{Cells}

Human erythroleukemic K562 cell line was obtained from American type culture collection (ATCC; Manassas, VA, USA). P815 Fc $\gamma \mathrm{R}^{+}$murine cell line was from DSMZ, Braunschweig, Germany. K562 cell line was grown in Iscove's Modified Dulbecco's Medium (IMDM) supplemented with $20 \%$ fetal calf serum (FCS), while P815 cell line was grown in IMDM supplemented with 10\% FCS. Media and supplements were from Seromed (Berlin, Germany).

\section{$\underline{\text { 2.3. Polyclonal NK cell preparation }}$}

Human PBMCs were isolated from the blood of healthy volunteers by Ficoll-Hypaque centrifugation followed by separation using the MACS NK cell isolation kit II (Miltenyi Biotec, Bergisch Gladbach, Germany) according to manufacturer's protocol. Flow cytometric 
analysis to determine purity of NK cells showed that more than $95 \%$ of the cells were CD56+CD3- (not shown). NK cells were cultured using IMDM containing 10\% FCS, with or without $40 \mathrm{U} / \mathrm{ml}$ recombinant IL-15. For all experiments, freshly isolated NK cells or IL-15activated NK cells were simultaneously treated with or without ribavirin at indicated concentration for 5 days.

\subsection{Cytotoxicity assay and Flow cytofluorometric analysis}

Cytotoxicity of NK cells was determined by a $4 \mathrm{~h}$ coupled luminescent method using the “ACELLA-TOX ${ }^{\mathrm{TM},}$ kit (Cell Technology, Mountain View, CA, USA), as described [21]. K562 and P815 Fc $\gamma \mathrm{R}^{+}$cell lines were used as target cells. For redirected killing experiments, $1 \mu \mathrm{g} / \mathrm{ml}$ of the corresponding purified mAb was used. Flow cytometry (FACS Calibur; Becton Dickinson, Mountain View, CA, USA) was used for cell surface expression analysis.

\subsection{Cell cycle analysis}

Cell cycle was determined using a commercial kit (BD Biosciences, San Jose, CA, USA) following the manufacturer's instructions as described previously [22].

\subsection{Viability assay}

The effect of ribavirin on viability of IL-15-activated NK cells was assessed using CELL TITRE-GLO ${ }^{\text {TM }}$ luminescent cell viability assay (Promega, Mannheim, Germany). This assay is a homogenous method of determining the number of viable cells in culture based on the quantitation of ATP present, which signals the presence of metabolically active cells. After 5 days treatment with ribavirin $100 \mu \mathrm{l}$ cell suspension were incubated with $100 \mu \mathrm{l}$ of CELL TITRE-GLO ${ }^{\mathrm{TM}}$ reagent and contents were allowed to mix on an orbital shaker in accordance with the assay protocols, this resulted in cell lysis and generation of a luminescent signal proportional to the amount of ATP present. The amount of ATP is proportional to the number 
of cells present in culture. The luminescence signal was recorded with a luminometer

(Glomax; Promega, Mannheim, Germany). Trypan blue exclusion assay was additionally used to assess the amount of dead cells.

\subsection{NK cell degranulation experiment}

NK cells were stimulated by mAb cross-linking as previously described [15, 23]. Briefly, after 5 days of culture in $40 \mathrm{U} / \mathrm{ml} \mathrm{IL-15}$ with or without ribavirin, cells were labeled with 1 $\mu \mathrm{g} / \mathrm{ml}$ appropriate $\mathrm{mAbs}$ for $30 \mathrm{~min}$ at $4^{\circ} \mathrm{C}$. After washing, cells were stimulated with 10 $\mu \mathrm{g} / \mathrm{ml}$ AffiniPure F(ab') 2 Fragment Goat Anti-Mouse IgG (Jackson ImmunoResearch, West Grove, PA, USA) for $5 \mathrm{~min}$ at $37^{\circ} \mathrm{C}$. Reaction was stopped with ice-cold PBS. After overnight incubation at $37^{\circ} \mathrm{C}$, supernatants were collected for analysis and quantification of granule release by ELISA assay (Perforin/Granzyme B-ELISA kit, Diaclone Research, Besancon Cedex, France) according to manufacturer's instructions.

\subsection{Western blot}

Cells were cultured in IL-15 and in the presence or absence of ribavirin for $18 \mathrm{~h}$ and 5 days. Afterwards, Western blot analysis was performed as previously described [24]. Briefly, cell lysates were subjected to SDS-PAGE before transfer to nitrocellulose membranes (Schleicher \& Schuell, Dassel, Germany) using the Mini-Protean II system (Bio-Rad, Munich, Germany). After transfer, blots were blocked in tris-buffered saline (TBS) blocking buffer containing 3\% bovine serum albumin for $1 \mathrm{~h}$ at room temperature to saturate the non-specific protein-binding sites on the nitrocellulose membrane. The following primary rabbit polyclonal Abs were used: Jak-1, phospho-Jak-1 (tyrosine (Tyr)1022/1023), Jak-3, STAT-1, phospho-STAT-1 (Tyr701), STAT-3, phospho-STAT-3 (Tyr705), STAT-5, phospho-STAT-5 (Tyr694), ERK1/2, phospho-ERK1/2, JNK, phospho-JNK - all from Cell Signaling (Beverly, MA, USA). Phospho-Jak-3 (Tyr980) was from Santa Cruz biotechnology (Santa Cruz, CA, USA), mouse 
polyclonal beta actin Ab was from Sigma-Aldrich (Taufkirchen, Germany). The blots were incubated overnight with the primary $\mathrm{Ab}$ diluted in $\mathrm{TBS}$ at $4^{\circ} \mathrm{C}$ with gentle agitation.

Following a $1 \mathrm{~h}$ incubation period with peroxidase-conjugated secondary $\mathrm{Ab}$ at room temperature visualization was performed by enhanced chemiluminescence using a commercially available kit (Amersham, Liverpool, UK).

\subsection{Measurement of IFN- $\gamma$ production}

A total of $2 \times 10^{4} \mathrm{~K} 562$ cells were cocultured for $24 \mathrm{~h}$ with $1 \times 10^{5} \mathrm{NK}$ cells cultured in IL-15 and in the presence or absence of ribavirin. Both ribavirin-treated and untreated IL-15activated NK cells alone or K562 cells were used as control. Supernatants were collected and tested for production of IFN- $\gamma$. The amounts of IFN- $\gamma$ were determined using the Quantikine Human IFN- $\gamma$ ELISA kit (R\&D Systems, Wiesbaden, Germany) according to manufacturer's protocol.

\subsection{Statistics}

Values presented are the mean \pm standard error of mean (S.E.M) of at least three experiments. Comparisons between two groups were performed using Student's t-test. P-values lower than 0.05 were considered to be significant.

\subsection{Measurement of transcription factor activation}

The activation of nuclear factor kappa $\mathrm{B}(\mathrm{NF} \kappa \mathrm{B}) \mathrm{p} 50, \mathrm{NF \kappa B}$ p65, T-box expressed in $\mathrm{T}$ cells (T-bet), activator protein-1 (AP-1) (c-Jun), and nuclear factor of activated T cells (NFAT) in ribavirin-treated and untreated IL-15-activated NK cells was determined using TRANSAM ${ }^{\mathrm{TM}}$ ELISA kits (Active Motif, Carlsbad, CA, USA) for the corresponding transcription factor, according to manufacturer's protocols. 


\section{RESULTS}

\section{$\underline{\text { 3.1. Effect of RBV on viability of NK cells }}$}

We previously demonstrated that ribavirin neither induced a block in the cell cycle progression nor exerted cytotoxic effects in primary HUVEC at concentrations up to $20 \mu \mathrm{g} / \mathrm{ml}$ and $100 \mu \mathrm{g} / \mathrm{ml}$ respectively [25]. We therefore studied effects of ribavirin at concentrations ranging from $5 \mu \mathrm{g} / \mathrm{ml}$ to $80 \mu \mathrm{g} / \mathrm{ml}$ on viability of IL-15-activated NK cells. For this purpose, IL-15-activated NK cells were treated for 5 days with ribavirin. Dead cells were identified by fractional DNA content ("sub-G1 fraction"). Untreated NK cells were used as control. Results revealed ribavirin to be non-toxic to IL-15-activated NK cells at concentrations up to 40 $\mu \mathrm{g} / \mathrm{ml}$. At a concentration of $80 \mu \mathrm{g} / \mathrm{ml}$, ribavirin induced about $40 \%$ cell death in IL-15activated NK cells. Ribavirin also induced a G1 block in the cell cycle progression of the cells at concentrations ranging between $20 \mu \mathrm{g} / \mathrm{ml}$ and $80 \mu \mathrm{g} / \mathrm{ml}$ (Fig. 1A). Trypan blue and ATP release assays also revealed that ribavirin did not exert significant cytotoxic effect in IL-15activated NK cells at concentrations up to $20 \mu \mathrm{g} / \mathrm{ml}$ (Fig. 1B). The cell viability (ATP release) was however reduced to $59 \%$ at $80 \mu \mathrm{g} / \mathrm{ml}$ ribavirin concentration.

\subsection{Ribavirin suppresses NK cell cytotoxicity and IFN- $\gamma$ production}

The role of ribavirin on NK cell cytotoxicity was next investigated. Both freshly isolated NK cells and IL-15-activated NK cells were treated with $5 \mu \mathrm{g} / \mathrm{ml}, 10 \mu \mathrm{g} / \mathrm{ml}$, and $20 \mu \mathrm{g} / \mathrm{ml}$ ribavirin for 5 days after which the cytotoxicity against K562 cells was determined using a $4 \mathrm{~h}$ coupled luminescent method [21]. The results obtained show that ribavirin significantly suppressed IL-15-activated NK cell lysis of K562 in a dose-dependent manner (Fig. 2A). The $\%$ inhibition in comparison to control were $21 \%, 34.2 \%$, and $65.8 \%$ respectively for 5,10 , and $20 \mu \mathrm{g} / \mathrm{ml}$ ribavirin at an effector/target $(\mathrm{E} / \mathrm{T})$ ratio of $2: 1$. At $\mathrm{E} / \mathrm{T}$ ratio of $4: 1$, the $\%$ inhibition was $18.6 \%, 39 \%$, and $59.3 \%$ respectively for 5, 10, and $20 \mu \mathrm{g} / \mathrm{ml} \mathrm{RBV} \mathrm{(Fig.} \mathrm{2A).}$ On the other hand, ribavirin did not influence lysis of K562 target cells by freshly isolated NK 
cells (Fig. 2B). Since IL-15-activated NK cell cytotoxicity was inhibited upon simultaneous addition of IL-15 and ribavirin for 5 days, we tested the effect of ribavirin on IL-15-activated NK cells after $18 \mathrm{~h}$ ribavirin treatment. Here, NK cells were stimulated for 5 days with IL-15 (10 $\mathrm{ng} / \mathrm{ml}$ ) prior to addition of $20 \mu \mathrm{g} / \mathrm{ml}$ ribavirin. Results show a $23.8 \%$ reduction in lysis of K562 target cells in ribavirin-treated NK cells compared to untreated control (E/T ratio 4:1) but no ribavirin-induced cytotoxicity in NK cells (data not shown). The inhibition of NK cytotoxicity is known to be associated with inhibition of IFN- $\gamma$ production $[26,27]$. The production of INF- $\gamma$ by IL-15-activated NK cells was therefore measured upon coculture of IL-15-activated NK cells and ribavirin-treated IL-15-activated NK cells with K562 target cells. Ribavirin dose-dependently suppressed IFN- $\gamma$ production in IL-15-activated NK cells. The $\%$ inhibition in comparison to control was $28.1 \%, 49.1 \%$, and $67.7 \%$ respectively for 5 , 10, and $20 \mu \mathrm{g} / \mathrm{ml}$ ribavirin (Fig. 2C). As more than 50\% inhibition of NK lytic capacity and cytokine production was achieved by $20 \mu \mathrm{g} / \mathrm{ml}$ ribavirin treatment, and at this concentration ribavirin was not toxic to the cells, further experiments to clarify the mechanisms by which ribavirin inhibits IL-15-activated NK cell function were performed using $20 \mu \mathrm{g} / \mathrm{ml}$.

\subsection{Ribavirin suppresses NK cell cytotoxicity by mechanisms other than tetrahydrobiopterin or NO inhibition}

Previous studies indicated that ribavirin acts by inhibition of tetrahydrobiopterin, a cofactor of NO synthase enzymes, thereby leading to suppression of NO synthesis [25, 28]. We therefore investigated whether ribavirin suppressed IL-15-activated NK cell cytotoxicity by tetrahydrobiopterin inhibition. For this purpose, we exogenously added tetrahydrobiopterin or NO to ribavirin-treated and untreated IL-15-activated NK cells to demonstrate if inhibitory effects on NK cell cytotoxicity induced by ribavirin can be reversed by tetrahydrobiopterin or NO addition. The results obtained show that addition of tetrahydrobiopterin or NO did not reverse the inhibitory effects of ribavirin on IL-15-activated NK cell cytotoxicity (Fig. 3). 
While treatment of IL-15-activated NK cells with tetrahydrobiopterin alone did not influence NK cell lytic capacity treatment with NO alone significantly suppressed cytotoxicity of NK cells (Fig. 3).

\subsection{Ribavirin interferes with IL-15R expression and its associated downstream signaling events}

The results from NK cell cytotoxicity showed that only IL-15-activated NK cells were inhibited by ribavirin treatment. It is therefore likely that ribavirin interferes with signaling pathways involved in IL-15 activation of NK cells. We therefore analyzed for the expression of IL-15R $\alpha, \beta$, and $\gamma$ by flow cytometry as well as the Tyr phosphorylation of Jak-1, Jak-3, STAT-1, STAT-3, and STAT-5 by western blot in NK cells cultured in IL-15 and in the presence or absence of ribavirin. As shown in Fig. 4A, ribavirin inhibited IL-15R $\beta$ and $\gamma$ expression. IL-15R $\alpha$ expression was not changed (not shown). Also, Jak-1, STAT-1 and STAT-3 Tyr phosphorylation were sharply inhibited by ribavirin, while a weak inhibition of STAT-5 was observed (Fig 4B). Ribavirin did not inhibit Tyr phosphorylation of Jak-3 (Fig 4B). We also studied effect of ribavirin on IL-15 signaling after $18 \mathrm{~h} \mathrm{IL-15/ribavirin} \mathrm{treatment}$ of NK cells. The results obtained revealed the inhibition of Jak-1, STAT-1, STAT-3, but not Jak-3 and STAT-5 phosphorylation (Fig 4C). IL-2R $\beta$ and $\gamma$ expression was also suppressed (not shown) after $18 \mathrm{~h}$ ribavirin treatment.

\section{$\underline{\text { 3.5. Ribavirin down-modulates NK cell activating receptor expression }}$}

NK cell cytotoxicity is critically dependent on signaling through its receptors, leading to granule polarization and exocytosis. Since IL-15 enhances NK cell cytotoxicity by upregulating the expression of NK receptors, it is conceivable that the inhibition of IL-15 signaling via IL-15R $\beta$ and $\gamma$ by ribavirin might lead to a suppressed expression of NK cell receptors responsible for cytotoxicity signals. To address these issues, we investigated the 
surface expression patterns of NK cell triggering receptors NKp30, NKp44, NKp46, NKG2D and DNAM-1 as well as NK cell inhibitory receptors NKG2A, KIR3DL1 and KIR2DL2/DL3 in both untreated and ribavirin-treated IL-15-activated NK cells. A correlation between NK cell cytotoxicity and NK cell receptor expression pattern was observed. The lytic capacity of ribavirin-treated IL-15-activated NK cells was associated with a decreased surface expression of NKp30, NKp44, NKp46 and NKG2D in comparison to untreated control. No changes were observed in the surface expression of DNAM-1, NKG2A, KIR3DL1 and KIR2DL2/DL3 (Fig. 5A). Although not shown, ribavirin did not suppress the surface expression of triggering and inhibitory receptors in NK cells cultured without IL-15. Basically NK cell activating or inhibitory receptor expression levels were 3-4 folds higher in IL-15 cultured NK cells than in NK cells cultured without IL-15 (not shown). Since NK cytolysis also depends on binding mediated by adhesion molecules like LFA-1, we determined effects of ribavirin on LFA-1 surface expression. Ribavirin did not modify the expression of LFA-1 (Fig. 5A). These results suggest that ribavirin acts directly on selected NK cell receptors rather than by interfering with NK cell binding to target cells.

\subsection{Ribavirin suppresses NK cell receptor function}

To assess whether ribavirin-induced down-modulation of NK cell activating receptors correlated with an alteration of receptor function, ribavirin-treated and untreated NK cells were compared in a redirected killing assay against $\mathrm{Fc} \gamma \mathrm{R}^{+} \mathrm{P} 815$ target cell line. The $\mathrm{Fc} \gamma \mathrm{R}^{+}$ P815 cell line has been extensively used for mAb-mediated redirected killing assays using NK cells and mAbs capable of triggering their cytolytic functions [23, 29]. This would allow us assess in a cytolytic assay the direct effect of ribavirin on the specific activity of NK trigerring receptors. As shown in Fig. 5B, treatment of IL-15-activated NK cells with $20 \mu \mathrm{g} / \mathrm{ml}$ ribavirin significantly reduced the ability of anti-NKp30 (19.3 vs. 11-fold increase for untreated and ribavirin-treated IL-15-activated NK cells respectively compared to control), anti-NKp44 
(14.7 vs. 4-fold increase for untreated and ribavirin-treated IL-15-activated NK cells respectively compared to control), anti-NKp46 (20 vs. 14-fold increase for untreated and ribavirin-treated IL-15-activated NK cells respectively compared to control) and anti-NKG2D (10.7 vs. 1 -fold increase for untreated and ribavirin-treated IL-15-activated NK cells respectively compared to control) mAbs to induce NK cell-mediated lysis. The ability of antiDNAM-1 mAb to induce NK cell lysis was not significantly impaired by ribavirin treatment (14.7 vs. 14-fold increase for untreated and ribavirin-treated IL-15-activated NK cells respectively compared to control). These findings suggest that ribavirin impairs NK cell cytotoxicity by interfering with the expression and function of NKp30, NKp44, NKp46 and NKG2D triggering receptors.

\subsection{Ribavirin interferes with pathways involved in NK cell degranulation and impairs}

\section{$\underline{\text { NK cell granule release }}$}

Two downstream signaling pathways, ERK and JNK, have been implicated to be responsible for lytic granule polarization in NK cells [15, 30-34]. We therefore analyzed by western blot the phosphorylation of ERK1/2 and JNK in NK cells cultured in IL-15 and in the presence or absence of ribavirin. As revealed in Fig. 6A, ERK1/2 and JNK phosphorylation was inhibited by ribavirin. From the above results, it was therefore necessary to clarify whether the inhibition of ERK and JNK phosphorylation by ribavirin correlated with reduced granule expression and exocytosis. To this end, intracellular perforin and granzyme B expression was measured by flow cytometry in both untreated and ribavirin-treated IL-15-activated NK cells. Also perforin and granzyme B degranulation after stimulation of cells with $\mathrm{mAb}$ as described was analyzed. As shown in Fig. 6B, ribavirin inhibited both perforin and granzyme B expression in IL-15-activated NK cells. A sharp impairment of perforin and granzyme B release was also observed upon treatment of IL-15-activated NK cells with ribavirin (Fig. 6C and D). 


\section{DISCUSSION}

The data presented in this study show for the first time that ribavirin inhibits human NK cell function. Moreover, evidence is presented about the molecular mechanisms that underlie the immunomodulatory activities of ribavirin in NK cells. NK cells mediate host cell defenses by direct lysis of target cells and/or by production of IFN- $\gamma$ [30]. Suppression of NK-cell cytotoxicity may be associated with the inhibition of IFN- $\gamma$ production $[26,27]$. Our results show that while ribavirin had no effect on lytic activity of NK cells that are not treated with IL-15, it exerted a dose-dependent inhibition on the lytic activity of IL-15-treated NK cells. Ribavirin also dose-dependently inhibited the production of IFN- $\gamma$ in IL-15-activated NK cells. Although not shown, ribavirin also suppressed the function of IL-2-activated NK cells. Remarkably, we found that NK cells from different donors can display different susceptibilities to ribavirin treatment in the presence of IL-15. Thus, in 2 of 15 donors, cytotoxicity and IFN- $\gamma$ production was not inhibited by ribavirin treatment.

In an attempt to identify the possible mechanism by which ribavirin inhibits cytotoxicity of IL-15-activated NK cells, we investigated a mode of action that has been ascribed to ribavirin - the inhibition of tetrahydrobiopterin syntheis and hence NO synthesis inhibition [25, 28]. NO is a highly reactive free radical synthesized in vessel endothelium, immune cells, brain, and other tissues. NO-mediated cell death is prominent among the many paths the immune system uses to kill target cells $[28,35]$. While some studies suggest that NO blocks activation of NK and cytotoxic T lymphocyte cells [36-38], another report suggests that NO has no effect on lymphokine activated killer (LAK) cells [39]. Some more studies however showed that NO increases LAK activity [40-42]. Results presented in this report show that addition of tetrahydrobiopterin or exogenous NO to ribavirin-treated IL-15activated NK cells did not prevent ribavirin-induced inhibition of NK cell cytotoxicity. This indicates that ribavirin suppresses IL-15-activated NK cell cytotoxicity by a mechanism other than tetrahydrobiopterin or NO depletion. While treatment of IL-15-activated NK cells with 
tetrahydrobiopterin alone did not influence NK cell lytic capacity treatment with NO alone significantly suppressed cytotoxicity of NK cells. These experiments were performed with highest non-toxic concentrations of tetrahydrobiopterin $(10 \mu \mathrm{g} / \mathrm{ml})$ and $\mathrm{NO}(5 \mu \mathrm{g} / \mathrm{ml})$. Higher concentrations (tetrahydrobiopterin $(20 \mu \mathrm{g} / \mathrm{ml})$, NO $(10 \mu \mathrm{g} / \mathrm{ml}))$, turned out to be cytotoxic in NK cells.

Since inhibition of NK cell activity by ribavirin occurred when NK cells were treated with IL-15, it is conceivable that the inhibition of NK cell cytotoxicity and IFN- $\gamma$ production was due to the interference of ribavirin with IL-15 receptor expression and/or signaling in NK cells. IL-15 signaling via its receptors in NK cells involves the Tyr phosphorylation of Jak-1, Jak-3, STAT-1, STAT-3, and STAT-5 [13, 15, 43, 44]. The results presented in this report show that ribavirin suppressed expression of IL-15R $\beta$ and $\gamma$ in IL-15-activated NK cells. It also inhibited Tyr phosphorylation of Jak-1, STAT-1, STAT-3, but not Jak-3 and STAT-5 after $18 \mathrm{~h}$ IL-15/ribavirin treatment of NK cells. The inhibition of Jak-1, STAT-1 and STAT-3 phosphorylation remained after 5 days IL-15/ribavirin treatment of NK cells. In contrast to the previous report showing maximal STAT-5 activation after $18 \mathrm{~h}$ IL-15 stimulation of NK cells, and then abolishment of STAT-5 phosphorylation after $48 \mathrm{~h}$ IL-15 stimulation [45], we still found phosphorylated p-STAT- 5 as late as 5 days after start of IL-15 stimulation. Ribavirin caused a weak inhibition of STAT5 phosphorylation after 5 days. The reasons for the differences in kinetics of IL-15-induced STAT5 phosphorylation observed by Pillet et al. [45] and us remain obscure. However, there are distinct differences in the experimental procedures applied that may contribute to the varying results. While Pillet et al. [45] precultured human

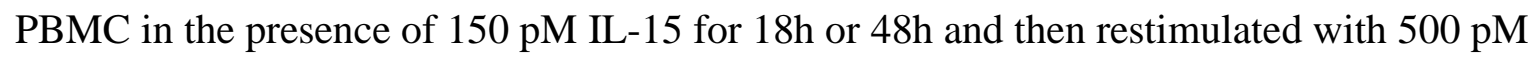
IL-15 for $15 \mathrm{~min}$, we treated NK cells with $10 \mathrm{ng} / \mathrm{ml} \mathrm{IL-15}$ for 5 days.

It is well established that IL-15R $\beta$ binds to Jak-1, which in turn, activates STAT-3 [13]. In this study, both Jak-1 and STAT-3 activation were inhibited by ribavirin. Therefore, ribavirin-induced inhibition of IL-15R $\beta$ expression may lead to a weak/impaired IL- 
15R $\beta /$ Jak-1 association and subsequently to blocking of Jak-1 and STAT-3 activation. Also, IL-15R $\gamma$ binds to Jak-3, which in turn, activates STAT-5 [13]. It appears that ribavirin does not impair the activation of Jak-3 by IL-15R $\gamma$ despite reduced expression of IL-15R $\gamma$. We have shown that STAT-5 phosphorylation was only weakly inhibited by ribavirin without a corresponding inhibition of Jak-3. A likely explanation for this phenomenon might be that signaling via IL-15R $\beta$ was directly responsible for STAT-5 phosphorylation and that STAT-5 phosphorylation may have been uncoupled from Jak-3 in ribavirin-treated IL-15-activated NK cells. This is in line with some reports that demonstrated that IL-15R $\beta$ directly phosphorylates STAT-5 [46, 47] and that neither the four cytoplasmic tyrosine residues of IL-15R $\gamma$ nor Jak-3 are required for STAT-5 induction [46]. It is not known whether IL-15 activation of Jak-1 or Jak-3 results in downstream phosphorylation of STAT-1. However, it has been reported that IL-15 activates STAT-1 phosphorylation [14, 15].

Different transcription factors are known to regulate the expression of IL-15R $\beta$ and $\gamma$ in NK cells. For instance, T-bet and Runx proteins were shown to regulate IL-15R $\beta$ expression [48-50], while NF- $\kappa \mathrm{B}$ was shown to be involved in IL-15R $\alpha$ and $\gamma$ expression [51]. It appeared possible that ribavirin might interfere with any of these transcription factors. To clarify this hypothesis, we simultaneously treated NK cells with IL-15 (10 ng/ml) and ribavirin $(20 \mu \mathrm{g} / \mathrm{ml})$ for $18 \mathrm{~h}$ and 5 days and thereafter performed transcription factor

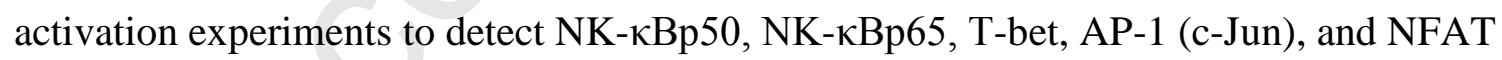
activation. Although not shown, ribavirin did not interfere with the activation of NK- $\mathrm{Bp} 50$, NK-кBp65, T-bet, AP-1 (c-Jun), and NFAT. This indicates that mechanisms other than

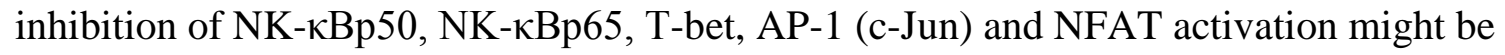
responsible for the reduced expression of IL-15R $\beta$ and $\gamma$ in ribavirin-treated NK cells.

NK cells treated with IL-15 generally exhibit increased cytotoxic potential when compared to resting NK cells because of increased expression of NK cell receptors and granules [14]. Since IL-15 signaling via its receptors was impaired by ribavirin, other 
downstream events involved in NK cytotoxicity such as NK cell receptors expression, NK cell signaling via its receptors, lytic granule expression, and lytic granule polarization and release, may also be suppressed. It is generally thought that integration of positive and negative signals from activating and inhibitory receptors determines downstream signaling events. Signals emanating from activating and inhibitory receptors determine the repertoire of NK receptors expressed on developing NK cells and regulate effector functions such as cytotoxicity and the production of IFN- $\gamma$ [52]. In this regard, several reports demonstrated that inhibition of NK cytotoxicity is associated with suppression of activating receptor expression on the cell surface of NK cells $[15,23,29,53]$. The results presented in this study show that ribavirin selectively down-regulated NK triggering receptors like NKp30, NKp44, NKp46, and NKG2D- and hence their function, while DNAM-1 and the adhesion molecule LFA-1 expression did not change. The inhibitory receptors like NKG2A, KIR2DL2/DL3, and KIR3DL1 were also not affected by ribavirin treatment. Although not shown, we did observe a 3 to 6-fold increase in the expression of activating receptors upon IL-15 treatment of NK cells for 5 days. This increased expression was reduced 2 to 3 -fold by ribavirin, however not to the level of expression in non-activated NK cells.

The ligation of NK cell with its target rapidly causes a transient activation of ERK, which apparently control lytic granule movement [31]. Indeed, the activation of the mitogenactivated protein kinase (MAPK) pathways, ERK1/2 and JNK, by activating receptors like NKp46, CD16, 2B4, and NKG2D [15, 33] has been reported to play a pivotal role in NK cell cytotoxicity and granule polarization. ERK2 in particular was reported to be the final mediator of perforin and granzyme B granule polarization towards target cells [31]. JNK was shown to be implicated in the prevention of down-regulation of NKG2D expression in NK cells by transforming growth factor beta [34]. Notably, in the presence of ribavirin, the inhibition of ERK1/2 activation was observed. JNK activation was only moderately inhibited by ribavirin. Although IL-15 mainly phosphorylates ERK1/2, it also does phosphorylate JNK. 
In T cells, IL-15 phosphorylation of ERK and JNK was shown to be mediated by NKG2D, an NK activating receptor which is up-regulated by IL-15 [54, 55]. Furthermore NKG2D signaling in NK cells is known to be coupled to IL-15 signaling [20]. It is therefore conceivable that inhibition of NK activating receptors expression, which in turn leads to impaired receptor signaling, may delineate how ribavirin blocks ERK1/2 and JNK activation. Additionally, inhibition of expression as well as a sharp decrease of release of perforin and granzyme B was detected in ribavirin-treated cells.

Ribavirin effects on IFN- $\gamma$ production were measured in NK cells stimulated by coincubation with target K562 cell line. In this case, IFN- $\gamma$ production relies on signaling pathways triggered by engagement of NK cell activating receptors. Interestingly, although many NK cell activating receptors signal through ITAM containing transmembrane adaptors (Dap12, FcR $\gamma$, and $\mathrm{CD} 3 \zeta$ ) distinct signaling intermediates within the ITAM pathway are variably involved in cytotoxicity and/or IFN- $\gamma$ secretion [56-58]. Early signaling events through ITAM which require activation of protein tyrosine kinases Syk and ZAP70, or downstream events including activation of phosphoinositol 3-kinase (PI3K) and MAPKs including ERK and JNK are important for IFN- $\gamma$ production. Moreover, NK cell activating receptors require protein kinase $\mathrm{C}-\theta(\mathrm{PKC}-\theta)$ to generate sustained intracellular ERK and JNK signals that reach the nucleus and promote transcriptional activation, ultimately inducing IFN- $\gamma$ production [59]. In the present study, effects of ribavirin on pathways upstream of MAPKs were not investigated. However, the inhibition of ERK1/2 and JNK phosphorylation in ribavirin treated NK cells may be relevant for inhibition of IFN- $\gamma$ production.

Other clinically used substances such as steroids have been shown to exert similar inhibitory effects on NK cell cytotoxicity like those described here for ribavirin. For instance, methylprednisolone down-regulated and impaired function of triggering receptors involved in NK cytototoxicity $[15,29]$. It also inhibited Jak/STAT and ERK1/2 signaling as well as 
granule release in IL-2/IL-15-activated NK cells [15]. Cortisol was also reported to inhibit NK function and repress cytokine, perforin mRNA and granzyme A syntheses [60]. It is therefore possible that ribavirin in viral diseases may suppress inflammatory responses through this "steroid-like" effects. In fact combination therapy with ribavirin seems to decrease the stimulatory effects of INF- $\alpha$ on NK cells in chronic HCV patients [61]. In concordance, ribavirin was shown to exert anti-inflammatory effect and reduced IFN- $\gamma$-driven T cell activation in chronic HCV patients [6].

Taken together, this report provides novel mechanisms by which ribavirin exerts its immunomodulatory activities. Ribavirin co-ordinately suppressed NK cell effector functions by inhibiting IL-15R $\beta$ and $\gamma$ expression and signaling and thus impairing downstream events involved in NK cell cytotoxicity including decrease in NK cell activating receptors expression and function, decrease in ERK1/2 and JNK activation, as well as decrease in levels of granzyme B and perforin expression and release. 


\section{ACKNOWLEDGEMENT}

The authors gratefully acknowledge the support by the organization "Hilfe für krebskranke

Kinder, Frankfurt/Main e.V.", by the foundation "Frankfurter Stiftung für krebskranke

Kinder.”, and by the European Commission-funded Co-operative Research and Specific

Targeted Research Projects; COOP-CT-2004, Contract Nr. 512864 and LSHB-CT-2004, Contract Nr. 512054 respectively.

The authors wish to thank Rosy Schmidt for her excellent technical assistance. 


\section{REFERENCES}

[1] Ohmit SE, Moler FW, Monto AS, Khan, AS. Ribavirin utilization and clinical effectiveness in children hospitalized with respiratory syncytial virus infection. J Clin Epidemiol 1996;49:963-7.

[2] Di Bisceglie AM, Thompson J, Smith-Wilkaitis N, Brunt EM, Bacon BR. Combination of interferon and ribavirin in chronic hepatitis C: re-treatment of nonresponders to interferon. Hepatology 2001;33:704-7.

[3] Ferenci P, Stauber R, Steindl-Munda P, Gschwantler M, Fickert P, Datz C, et al. Treatment of patients with chronic hepatitis $\mathrm{C}$ not responding to interferon with highdose interferon alpha with or without ribavirin: final results of a prospective randomized trial. Austrian Hepatitis Study Group. Eur J Gastroenterol Hepatol 2001;13:699-705.

[4] Graci JD, Cameron CE. Mechanisms of action of ribavirin against distinct viruses. Rev Med Virol 2006;16:37-48.

[5] Hultgren C, Milich DR, Weiland O, Sällberg M. The antiviral compound ribavirin modulates the T helper (Th) 1/Th2 subset balance in hepatitis B and C virus-specific immune responses. J Gen Virol 1998;79:2381-91.

[6] Bergamini A, Bolacchi F, Cepparulo M, Demin F, Uccella I, Bongiovanni B, et al. Treatment with ribavirin and interferon-alpha reduces interferon-gamma expression in patients with chronic hepatitis C. Clin Exp Immunol 2001;123:459-64.

[7] Ning Q, Brown D, Parodo J, Cattral M, Gorczynski R, Cole E, et al. Ribavirin inhibits viral-induced macrophage production of TNF, IL-1, the procoagulant fgl2 
prothrombinase and preserves Th1 cytokine production but inhibits Th2 cytokine response. J Immunol 1998;160:3487-93.

[8] Barnes E, Salio M, Cerundolo V, Medlin J, Murphy S, Dusheiko G, et al. Impact of alpha interferon and ribavirin on the function of maturing dendritic cells. Antimicrob Agents Chemother 2004;48:3382-9.

[9] Chen QY, Yang JQ, Mi CM. Effect of ribavirin on NK activities of murine spleen cells in vitro Yao Xue Xue Bao 1995;30:417-21.

[10] Moretta L, Bottino C, Pende D, Vitale M, Mingari MC, Moretta A. Human natural killer cells: Molecular mechanisms controlling NK cell activation and tumor cell lysis. Immunol Lett 2005;100:7-13.

[11] Waldmann TA, Tagaya Y. The multifaceted regulation of interleukin-15 expression and the role of this cytokine in NK cell differentiation and host response to intracellular pathogens. Annu Rev Immunol 1999;17:19-49.

[12] Zhang Y, Jamaluddin M, Wang S, Tian B, Garofalo RP, Casola A, et al. Ribavirin treatment up-regulates antiviral gene expression via the interferon-stimulated response element in respiratory syncytial virus-infected epithelial cells. J Virol 2003;77:593347.

[13] Fehniger TA, Cooper MA, Caligiuri MA. Interleukin-2 and interleukin-15: immunotherapy for cancer. Cytokine Growth Factor Rev 2002;13:169-83.

[14] Zhang C, Zhang J, Niu J, Zhang J, Tian Z. Interleukin-15 improves cytotoxicity of natural killer cells via up-regulating NKG2D and cytotoxic effector molecule expression as well as STAT1 and ERK1/2 phosphorylation. Cytokine 2008;42:128-36. 
[15] Chiossone L, Vitale C, Cottalasso F, Moretti S, Azzarone B, Moretta L, et al. Molecular analysis of the methylprednisolone-mediated inhibition of NK-cell function: evidence for different susceptibility of IL-2- versus IL-15-activated NK cells. Blood 2007;109:3767-75.

[16] Kogure T, Mantani N, Goto H, Shimada Y, Tamura J, Terasawa K. The effect of interleukin-15 on the expression of killer-cell immunoglobulin-like receptors on peripheral natural killer cells in human. Mediators Inflamm 2002;11:219-24.

[17] de Rham C, Ferrari-Lacraz S, Jendly S, Schneiter G, Dayer JM, Villard J. The proinflammatory cytokines IL-2, IL-15 and IL-21 modulate the repertoire of mature human natural killer cell receptors. Arthritis Res Ther 2007;9:R125.

[18] Lanier LL. NK cell recognition. Annu Rev Immunol 2005;23:225-74.

[19] Wu J, Song Y, Bakker AB, Bauer S, Spies T, Lanier LL, Phillips JH. An activating immunoreceptor complex formed by NKG2D and DAP10. Science 1999;285:7302.8

[20] Horng T, Bezbradica JS, Medzhitov R. NKG2D signaling is coupled to the interleukin 15 receptor signaling pathway. Nat Immunol 2007; 8:1345-52.

[21] Ogbomo H, Michaelis M, Klassert D, Doerr HW, Cinatl J Jr. Resistance to cytarabine induces the up-regulation of NKG2D ligands and enhances natural killer cell lysis of leukemic cells. Neoplasia 2008;10:1402-10.

[22] Michaelis M, Suhan T, Michaelis UR, Beek K, Rothweiler F, Tausch L, et al. Valproic acid induces extracellular signal-regulated kinase 1/2 activation and inhibits apoptosis in endothelial cells. Cell Death Differ 2006;13:446-53. 
[23] Ogbomo H, Michaelis M, Kreuter J, Doerr HW, Cinatl J Jr. Histone deacetylase inhibitors suppress natural killer cell cytolytic activity. FEBS Lett 2007;581:1317-22.

[24] Blaheta RA, Weich E, Marian D, Bereiter-Hahn J, Jones J, Jonas D, et al Human cytomegalovirus infection alters PC3 prostate carcinoma cell adhesion to endothelial cells and extracellular matrix. Neoplasia 2006;8:807-16.

[25] Michaelis M, Michaelis R, Suhan T, Schmidt H, Mohamed A, Doerr HW, et al. Ribavirin inhibits angiogenesis by tetrahydrobiopterin depletion. FASEB J $2007 ; 21: 81-7$

[26] Kim KY, Kim JK, Han SH, Lim JS, Kim KI, Cho DH, et al. Adiponectin is a negative regulator of NK cell cytotoxicity. J Immunol 2006;176:5958-64.

[27] Li A, He M, Wang H, Qiao B, Chen P, Gu H, et al. All-trans retinoic acid negatively regulates cytotoxic activities of nature killer cell line 92. Biochem Biophys Res Commun 2007;352:42-7.

[28] Kast RE. Ribavirin in cancer immunotherapies: controlling nitric oxide augments cytotoxic lymphocyte function. Neoplasia 2003;5:3-8.

[29] Vitale C, Chiossone L, Cantoni C, Morreale G, Cottalasso F, Moretti S, et al. The corticosteroid-induced inhibitory effect on NK cell function reflects down-regulation and/or dysfunction of triggering receptors involved in natural cytotoxicity. Eur $\mathbf{J}$ Immunol 2004;34:3028-38.

[30] Liang S, Zhang J, Wei H, Sun R, Tian Z. Differential roles of constitutively activated ERK1/2 and NF-kappa B in cytotoxicity and proliferation by human NK cell lines. Int Immunopharmacol 2005;5:839-48. 
[31] Wei S, Gamero AM, Liu JH, Daulton AA, Valkov NI., Trapani JA, et al. Control of lytic function by mitogen-activated protein kinase/extracellular regulatory kinase 2 (ERK2) in a human natural killer cell line: identification of perforin and granzyme B mobilization by functional ERK2. J Exp Med 1998;187:1753-65.

[32] Chen X, Allan DS, Krzewski K, Ge B, Kopcow H, Strominger JL. CD28-stimulated ERK2 phosphorylation is required for polarization of the microtubule organizing center and granules in YTS NK cells. Proc Natl Acad Sci U S A 2006;103:10346-51.

[33] Li C, Ge B, Nicotra M, Stern JN, Kopcow HD, Chen X, et al. JNK MAP kinase activation is required for MTOC and granule polarization in NKG2D-mediated NK cell cytotoxicity. Proc Natl Acad Sci U S A 2008;105:3017-22.

[34] Song H, Hur DY, Kim KE, Park H, Kim T, Kim CW, et al. IL-2/IL-18 prevent the down-modulation of NKG2D by TGF-beta in NK cells via the c-Jun N-terminal kinase (JNK) pathway. Cell Immunol 2006;242:39-45.

[35] Bogdan C, Röllinghoff M, Diefenbach A. The role of nitric oxide in innate immunity. Immunol Rev 2000;173:17-26.

[36] Ferlito M, Irani K, Faraday N, Lowenstein CJ. Nitric oxide inhibits exocytosis of cytolytic granules from lymphokine-activated killer cells. Proc Natl Acad Sci U S A 2006;103:11689-94.

[37] Kurose I, Miura S, Saito H, Tada S, Fukumura D, Higuchi H, et al Rat Kupffer cellderived nitric oxide modulates induction of lymphokine-activated killer cell. Gastroenterology 1995;109:1958-68. 
[38] Orucevic A, Lala PK. Effects of N(G)-Nitro-L-arginine methyl ester, an inhibitor of nitric oxide synthesis, on IL-2-induced LAK cell generation in vivo and in vitro in healthy and tumor-bearing mice. Cell Immunol 1996;169:125-32.

[39] Salvucci O, Kolb JP, Dugas B, Dugas N, Chouaib S. The induction of nitric oxide by interleukin-12 and tumor necrosis factor-alpha in human natural killer cells: relationship with the regulation of lytic activity. Blood 1998;92:2093-102.

[40] Cifone MG, Festuccia C, Cironi L, Cavallo G, Chessa MA, Pensa V, et al Induction of the nitric oxide-synthesizing pathway in fresh and interleukin 2-cultured rat natural killer cells. Cell Immunol 1994;157:181-94.

[41] Juretic A, Spagnoli GC, von Bremen K, Hörig H, Filgueira L, Lüscher U, et al. Generation of lymphokine-activated killer activity in rodents but not in humans is nitric oxide dependent. Cell Immunol 1994;157:462-77.

[42] Yim CY, McGregor JR, Kwon OD, Bastian NR, Rees M, Mori M, et al. Nitric oxide synthesis contributes to IL-2-induced antitumor responses against intraperitoneal Meth A tumor. J Immunol 1995; 155:4382-90.

[43] Johnston JA, Bacon CM, Finbloom DS, Rees RC, Kaplan D, Shibuya K, et al. Tyrosine phosphorylation and activation of STAT5, STAT3, and Janus kinases by interleukins 2 and 15. Proc Natl Acad Sci U S A 1995;92:8705-9.

[44] O'Sullivan LA, Liongue C, Lewis RS, Stephenson SE, Ward AC. Cytokine receptor signaling through the Jak-Stat-Socs pathway in disease. Mol Immunol 2007;44:2497506. 
[45] Pillet AH, Bugault F, Thèze J, Chakrabarti LA, Rose T. A programmed switch from IL-15- to IL-2-dependent activation in human NK cells. J Immunol 2009;182:6267-77.

[46] Gaffen SL, Lai SY, Ha M, Liu X, Hennighausen L, Greene WC, et al. Distinct tyrosine residues within the interleukin-2 receptor beta chain drive signal transduction specificity, redundancy, and diversity. J Biol Chem 1996;271:21381-90.

[47] Ascherman DP, Migone TS, Friedmann MC, Leonard WJ. Interleukin-2 (IL-2)mediated induction of the IL-2 receptor alpha chain gene. Critical role of two functionally redundant tyrosine residues in the IL-2 receptor beta chain cytoplasmic domain and suggestion that these residues mediate more than Stat5 activation. J Biol Chem 1997;272:8704-9.

[48] Matsuda JL, George TC, Hagman J, Gapin L. Temporal dissection of T-bet functions. J Immunol 2007;178:3457-65.

[49] Glimcher LH, Townsend MJ, Sullivan BM, Lord GM. Recent developments in the transcriptional regulation of cytolytic effector cells. Nat Rev Immunol 2004;4:900-11.

[50] Ohno S, Sato T, Kohu K, Takeda K, Okumura K, Satake M, et al.. Runx proteins are involved in regulation of CD122, Ly49 family and IFN-gamma expression during NK cell differentiation. Int Immunol 2008;20:71-9.

[51] Vallabhapurapu S, Powolny-Budnicka I, Riemann M, Schmid RM, Paxian S, Pfeffer K, et al. Rel/NF-kappaB family member RelA regulates NK1.1- to NK1.1+ transition as well as IL-15-induced expansion of NKT cells. Eur J Immunol 2008;38:3508-19.

[52] Yokoyama WM, Kim S, French AR. The dynamic life of natural killer cells. Annu Rev Immunol 2004;22:405-29. 
[53] Chiesa MD, Carlomagno S, Frumento G, Balsamo M, Cantoni C, Conte R, et al. The tryptophan catabolite L-kynurenine inhibits the surface expression of NKp46- and NKG2D-activating receptors and regulates NK-cell function. Blood 2006;108:411825.

[54] Tang F, Chen Z, Ciszewski C, Setty M, Solus J, Tretiakova M, et al. Cytosolic PLA2 is required for CTL-mediated immunopathology of celiac disease via NKG2D and IL15. J Exp Med 2009;206:707-19.

[55] Meresse B, Chen Z, Ciszewski C, Tretiakova M, Bhagat G, Krausz TN, et al. Coordinated induction by IL15 of a TCR-independent NKG2D signaling pathway converts CTL into lymphokine-activated killer cells in celiac disease. Immunity 2004;21:357-66.

[56] Schoenborn JR, Wilson CB. Regulation of interferon-gamma during innate and adaptive immune responses. Adv Immunol 2007;96:41-101.

[57] Lanier LL. Up on the tightrope: natural killer cell activation and inhibition. Nat Immunol 2008;9:495-502.

[58] Bryceson YT, Long EO. Line of attack: NK cell specificity and integration of signals. Curr Opin. Immunol 2008;20:344-52.

[59] Tassi I, Cella M, Presti R, Colucci A, Gilfillan S, Littman DR, et al. NK cell-activating receptors require PKC-theta for sustained signaling, transcriptional activation, and IFN-gamma secretion. Blood 2008;112:4109-16. 
[60] Zhou J, Olsen S, Moldovan J, Fu X, Sarkar FH, Moudgil VK, et al. Glucocorticoid regulation of natural cytotoxicity: effects of cortisol on the phenotype and function of a cloned human natural killer cell line. Cell Immunol 1997;178:108-16.

[61] Fang SH, Lai MY, Hwang LH, Yang PM, Chen PJ, Chiang BL, et al. Ribavirin enhances interferon-gamma levels in patients with chronic hepatitis $\mathrm{C}$ treated with interferon-alpha. J Biomed Sci 2001;8:484-91. 


\section{FIGURE CAPTIONS}

Figure 1. Influence of ribavirin on cell cycle and viability of NK cells. Primary NK cells from healthy donors were cultured in $40 \mathrm{U} / \mathrm{ml} \mathrm{IL-15}$ and in the presence or absence of ribavirin at indicated concentrations for 5 days. A) The influence of ribavirin on cell cycle was determined by staining cells with propidium iodide. Values represent percentage of cells in the different phases. The percentages of cells in G1, S and G2/M phases were deduced from the number of viable cells (set to 100\%) after subtracting the dead cells (sub G1) from total gated cells. One representative of 3 different experiments is shown. B) Concentrationdependent influence of ribavirin on NK cell viability using both trypan blue exclusion and ATP release assays. Columns represent means of triplicate of one representative experiment; error bars indicate \pm S.E.M; $* P<0.05$ relative to control.

Figure 2. Effect of ribavirin on NK cell cytotoxicity and IFN- $\gamma$ production. A 4 h cytotoxicity assay against $5000 \mathrm{~K} 562$ target cells was performed at indicated E/T ratios using A) ribavirintreated and untreated (control) IL-15-activated NK cells and B) ribavirin-treated and untreated (control) NK cells. C). IFN- $\gamma$ production in ribavirin-treated and untreated (control) IL-15activated NK cells was measured as described in materials and methods. Columns represent means of triplicate of one representative experiment; error bars indicate \pm S.E.M; $* P<0.05$ relative to control.

Figure 3. Ribavirin does not suppress NK cytotoxicity by inhibiting tetrahydrobiopterin or NO. Primary NK cells from healthy donors were cultured in $40 \mathrm{U} / \mathrm{ml}$ IL-15 and in the presence or absence of $20 \mu \mathrm{g} / \mathrm{ml}$ ribavirin for 5 days. Tetrahydrobiopterin $(10 \mu \mathrm{M})$ or DETA NONO-ate (used as NO donor; $5 \mu \mathrm{M}$ ) was added to ribavirin-treated or untreated IL-15activated NK cells for the 5 days incubation period. IL-15-activated NK cells were used as control. A $4 \mathrm{~h}$ cytotoxicity assay against $5000 \mathrm{~K} 562$ target cells was performed at an E/T ratio 
of $4: 1$. Columns represent means of triplicate of one representative experiment; error bars indicate \pm S.E.M; $* P<0.05$ relative to control.

Figure 4. Ribavirin interferes with IL-15 signaling. NK cells were treated for $18 \mathrm{~h}$ or 5 days with IL-15 and in the presence or absence of $20 \mu \mathrm{g} / \mathrm{ml}$ ribavirin. A) Flow cytometric analysis for the expression of IL-15 receptors in NK cells treated with IL-15/ribavirin for 5 days. Grey line and black filled histogram indicate isotype control staining for untreated and ribavirintreated IL-15-activated NK cells respectively; grey filled histogram and black line indicate antibody staining for untreated and ribavirin-treated IL-15-activated NK cells respectively. One representative of at least 5 separate experiments is shown. B) The same amount of protein extracts prepared from ribavirin-treated and untreated IL-15-activated NK cells was used for western blot analysis of the indicated signaling proteins. Data are representative of at least three experiments.

Figure 5. Effect of ribavirin on NK cell receptor expression and function. NK cells were treated with IL-15 and in the presence or absence of $20 \mu \mathrm{g} / \mathrm{ml}$ ribavirin. A) Flow cytometric analysis for the expression of NK activating and inhibitory receptors. Grey line and black filled histogram indicate isotype control staining for untreated and ribavirin-treated IL-15activated NK cells respectively; grey filled histogram and black line indicate antibody staining for untreated and ribavirin-treated IL-15-activated NK cells respectively. One representative of at least 3 separate experiments is shown. B) A 4 h NK cell cytotoxicity was assessed in a redirected killing assay against the $\mathrm{Fc} \gamma \mathrm{R}^{+} \mathrm{P} 815$ target cell line either in the presence or absence of mAbs to the indicated receptors. Columns represent means of triplicate of one representative experiment; error bars indicate \pm S.E.M; ${ }^{*} P<0.05$ relative to control. 
Figure 6. Ribavirin interferes with NK cell degranulation pathway and granule exocytosis. NK cells were treated with IL-15 and in the presence or absence of $20 \mu \mathrm{g} / \mathrm{ml}$ ribavirin. A) The same amount of protein extracts prepared from ribavirin-treated and untreated IL-15-activated NK cells was used for western blot analysis of the indicated signaling proteins. Data are representative of at least three experiments. B) Flow cytometric analysis for the expression of perforin and granzyme B lytic granules in ribavirin-treated and untreated IL-15-activated NK cells. Grey line and black filled histogram indicate isotype control staining for untreated and ribavirin-treated IL-15-activated NK cells respectively; grey filled histogram and black line indicate antibody staining for untreated and ribavirin-treated IL-15-activated NK cells respectively. One representative of at least 3 experiments is shown. $\mathrm{C}$ and D) Ribavirintreated and untreated IL-15-activated NK cells were stimulated by cross-linking NK receptors with indicated $\mathrm{mAb}$. After overnight incubation at $37^{\circ} \mathrm{C}$ in IMDM $+10 \% \mathrm{FCS}$ alone, supernatants were collected and analyzed in an ELISA assay specific for in vitro quantitative determination of perforin and granzyme B release. Columns represent means of triplicate of one representative experiment; error bars indicate \pm S.E.M; $* P<0.05$ relative to control; $* * * P<0.05$ relative to $\mathrm{mAb}$ control. 
A

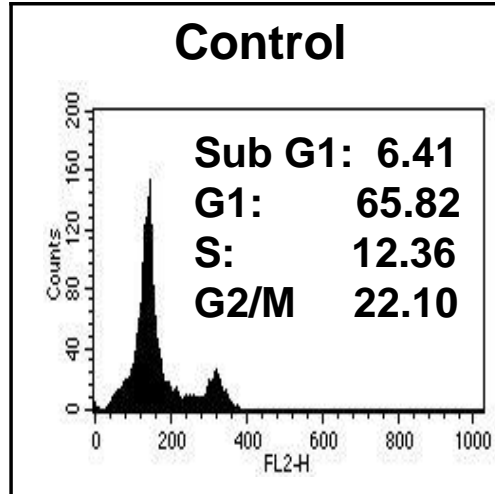

Ribavirin $10 \mu \mathrm{g} / \mathrm{ml}$

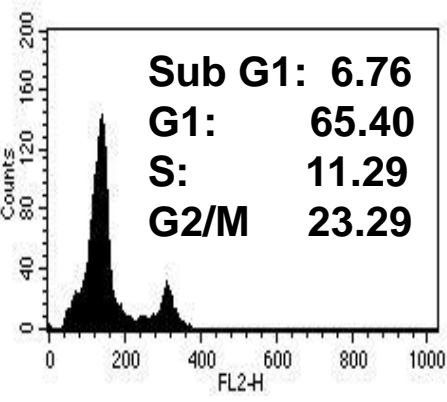

Ribavirin $40 \mu \mathrm{g} / \mathrm{ml}$

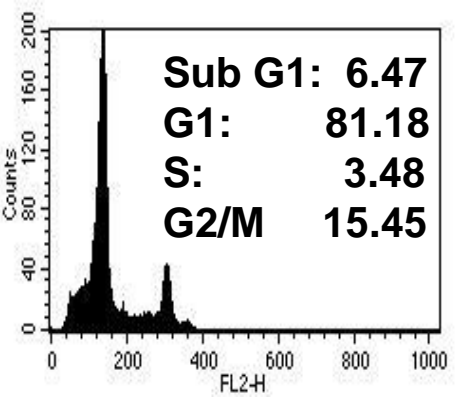

\section{Ribavirin $5 \mu \mathrm{g} / \mathrm{ml}$}

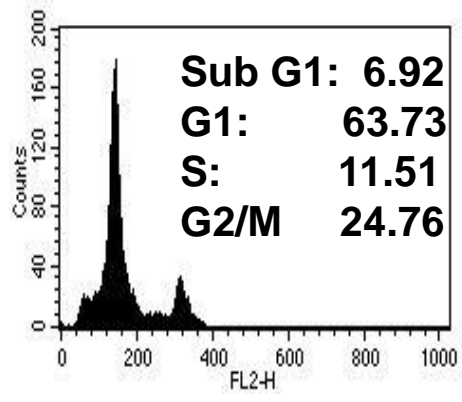

Ribavirin $20 \mu \mathrm{g} / \mathrm{ml}$

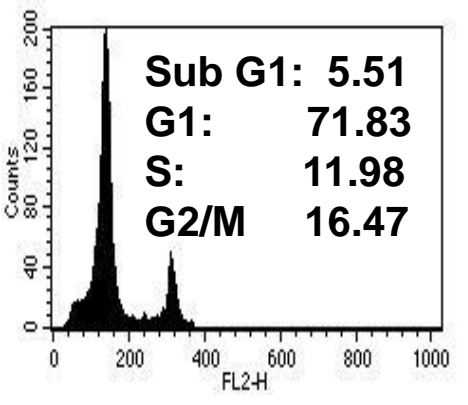

Ribavirin $80 \mu \mathrm{g} / \mathrm{ml}$

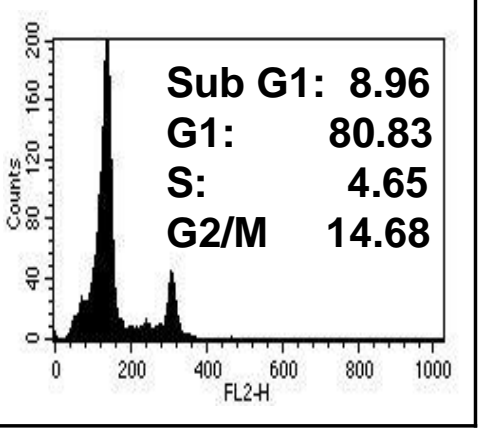

B

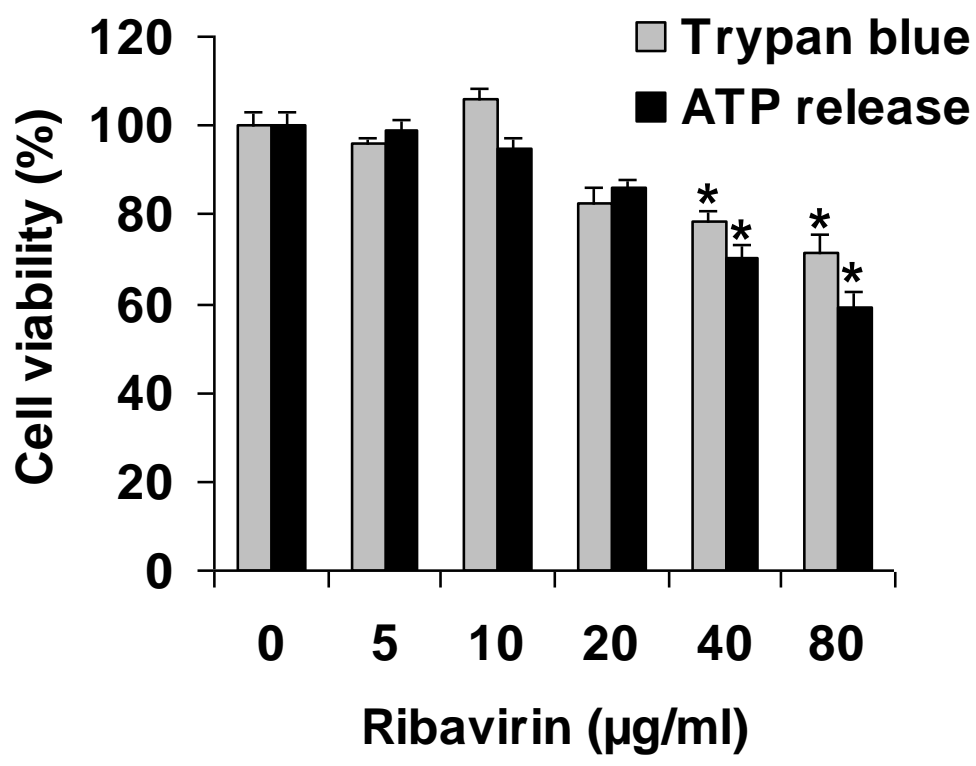


A

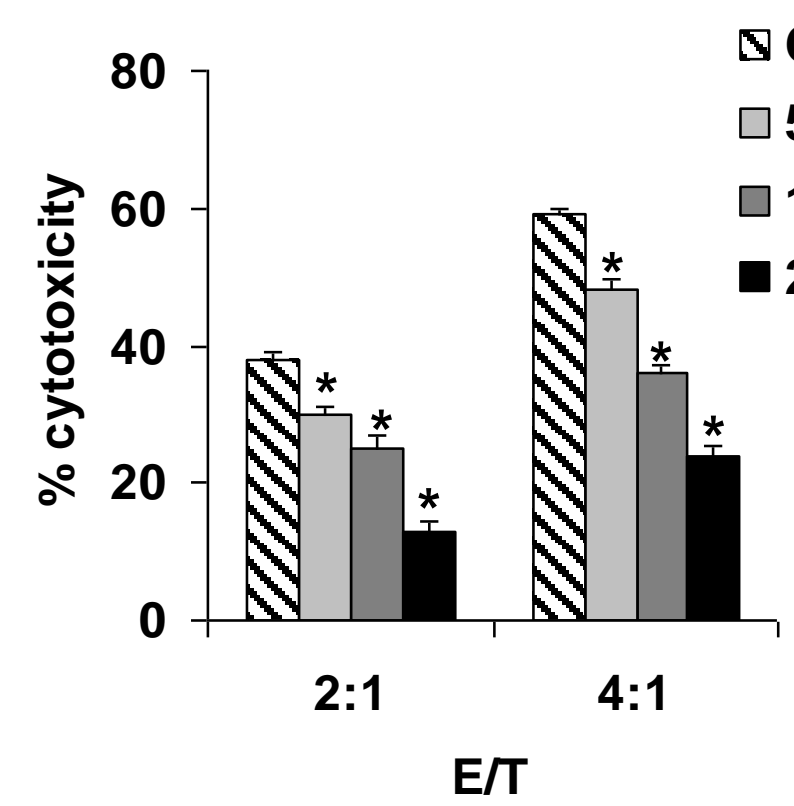

B

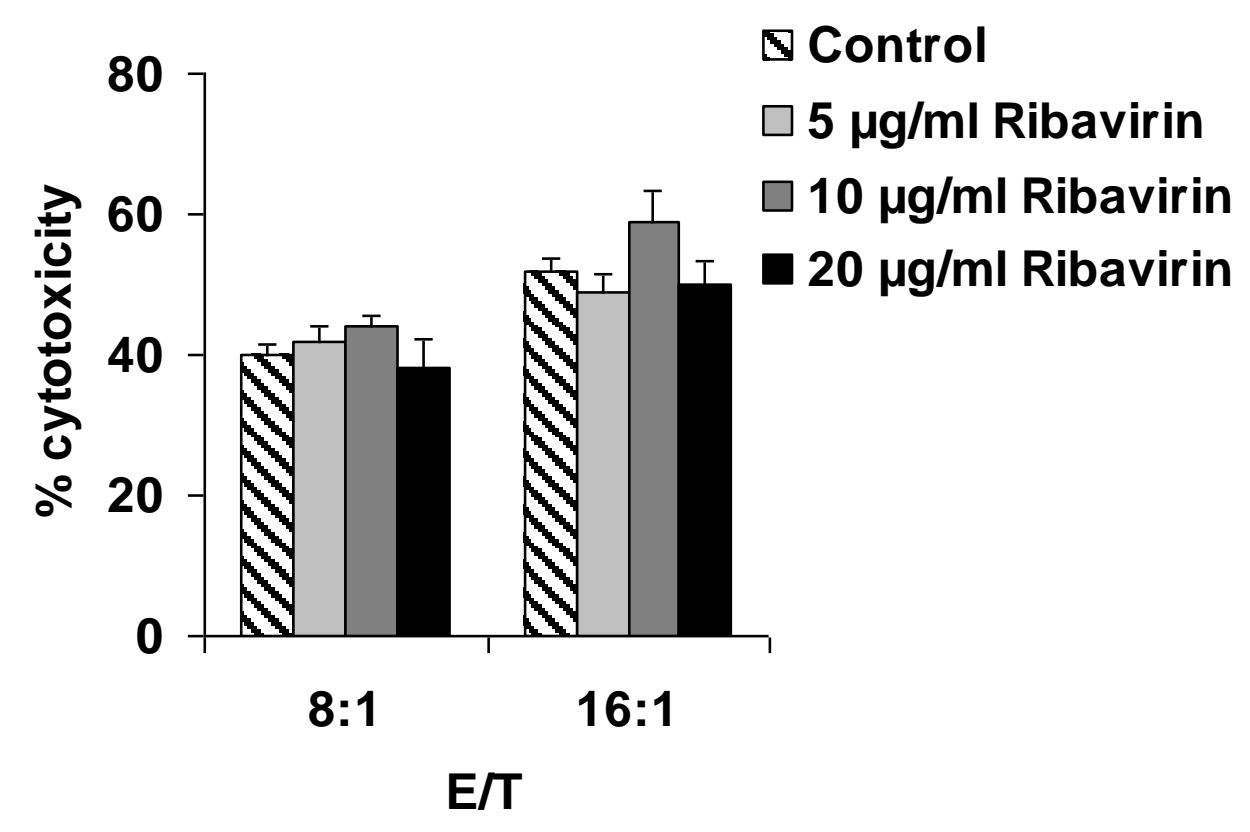

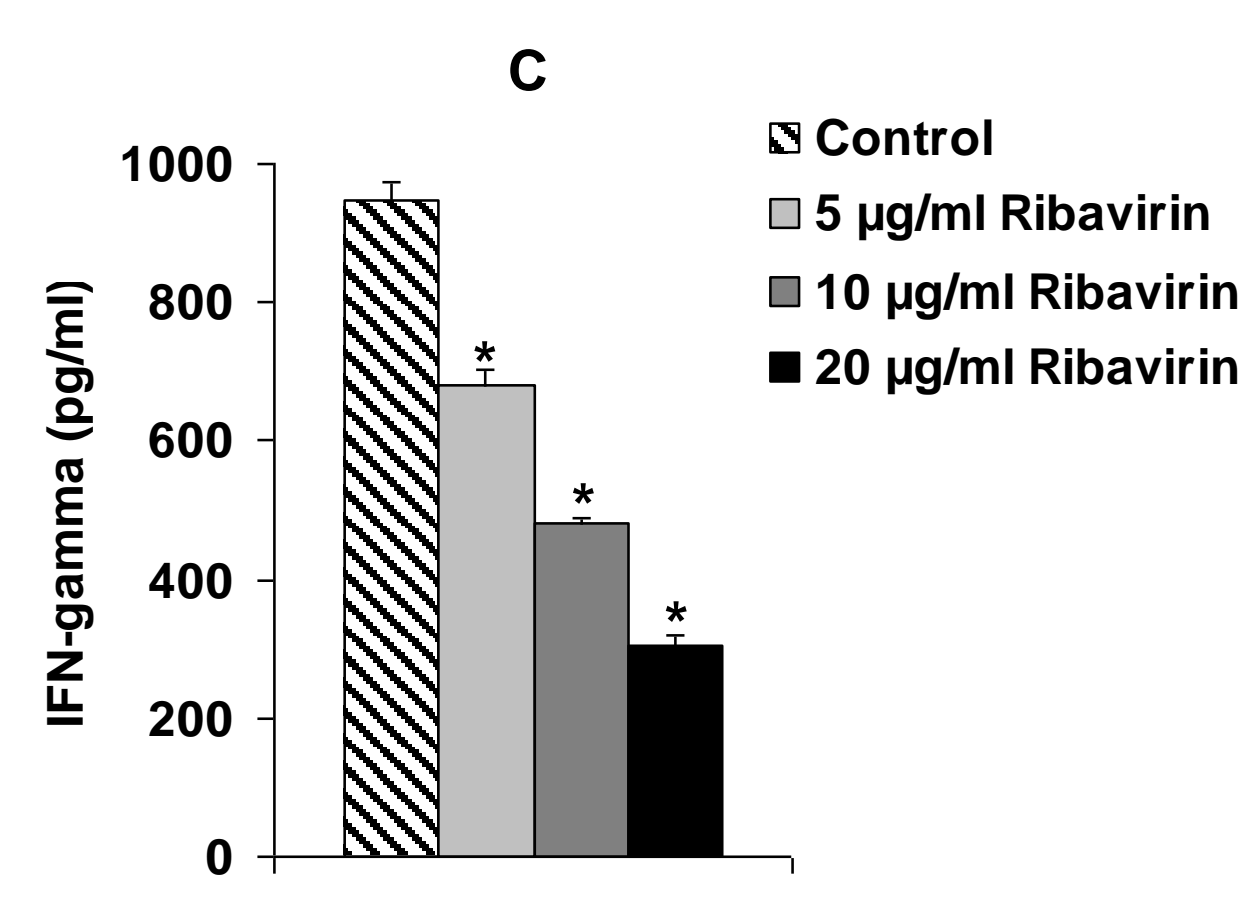

Control

$\square$ $5 \mathrm{~g} / \mathrm{ml}$ Ribavirin

$10 \mu \mathrm{g} / \mathrm{ml}$ Ribavirin

$20 \mu \mathrm{g} / \mathrm{ml}$ Ribavirin

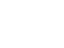




\section{Figure 3}

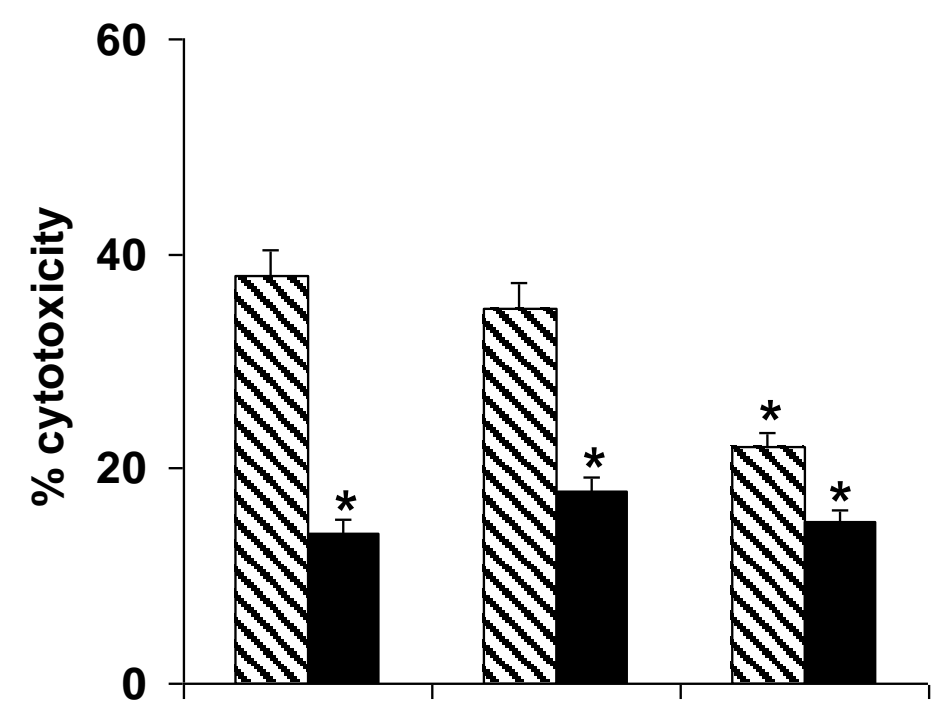

$\begin{array}{lcccccc}\text { Ribavirin } & - & + & - & + & - & + \\ \text { Tetrahydrobiopterin } & - & - & + & + & - & - \\ \text { NO } & - & - & - & - & + & +\end{array}$


Figure 4

A
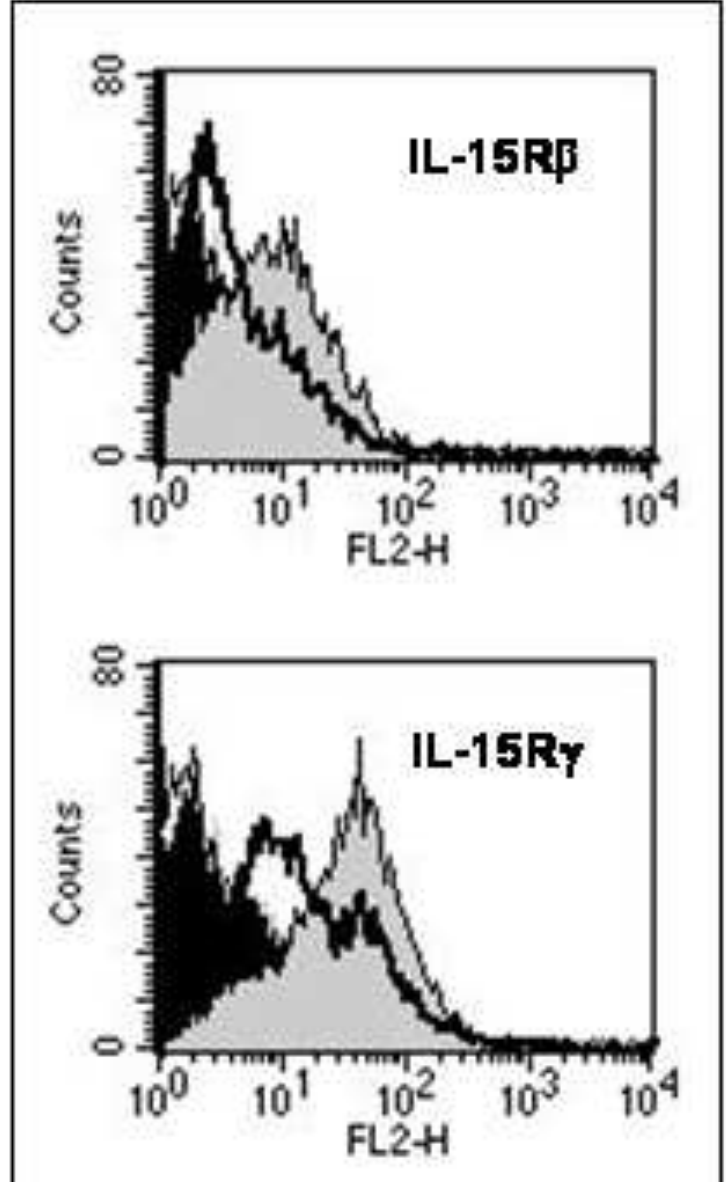

B

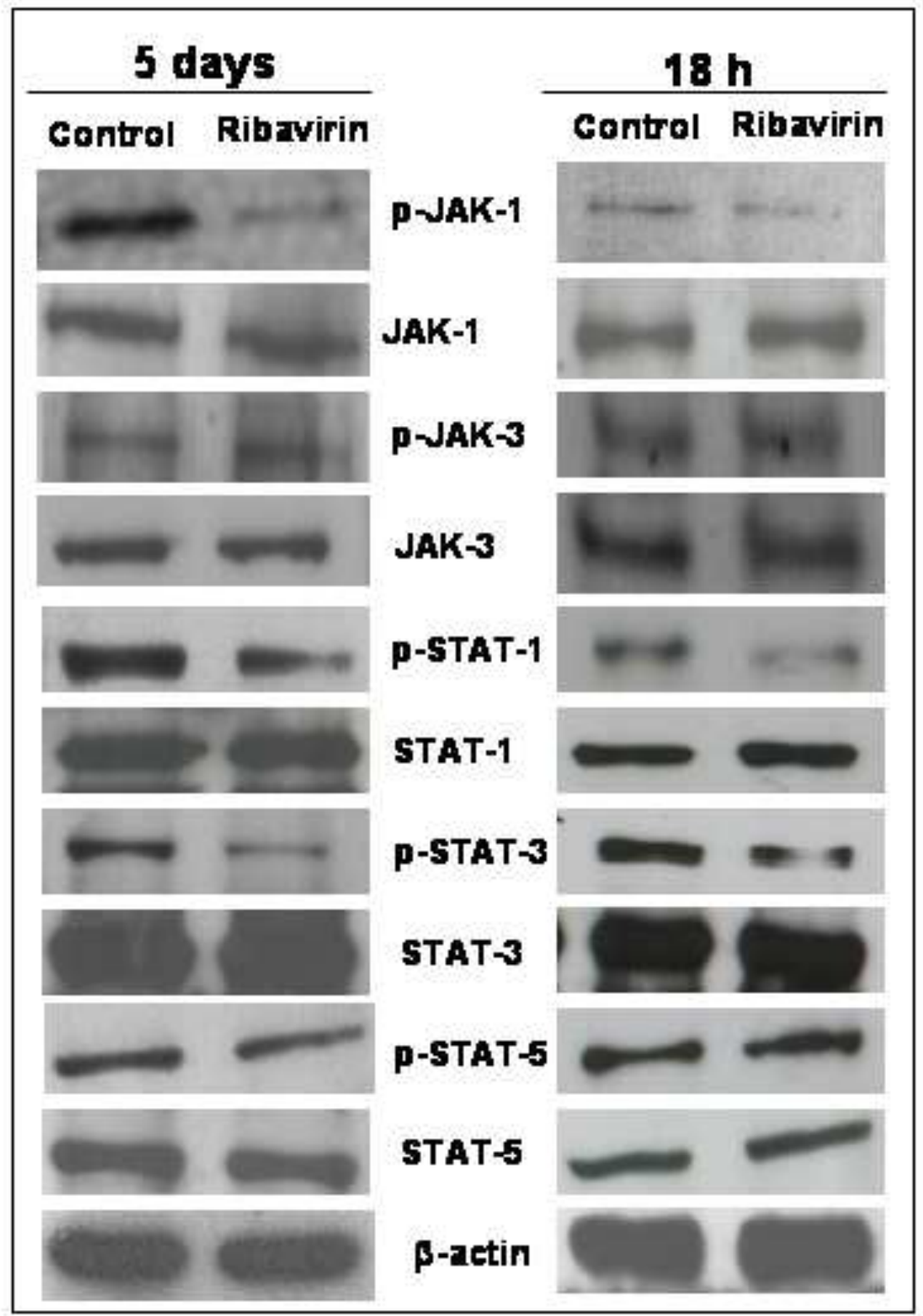

rage $3 /$ or 40 


\section{Figure 5}

A
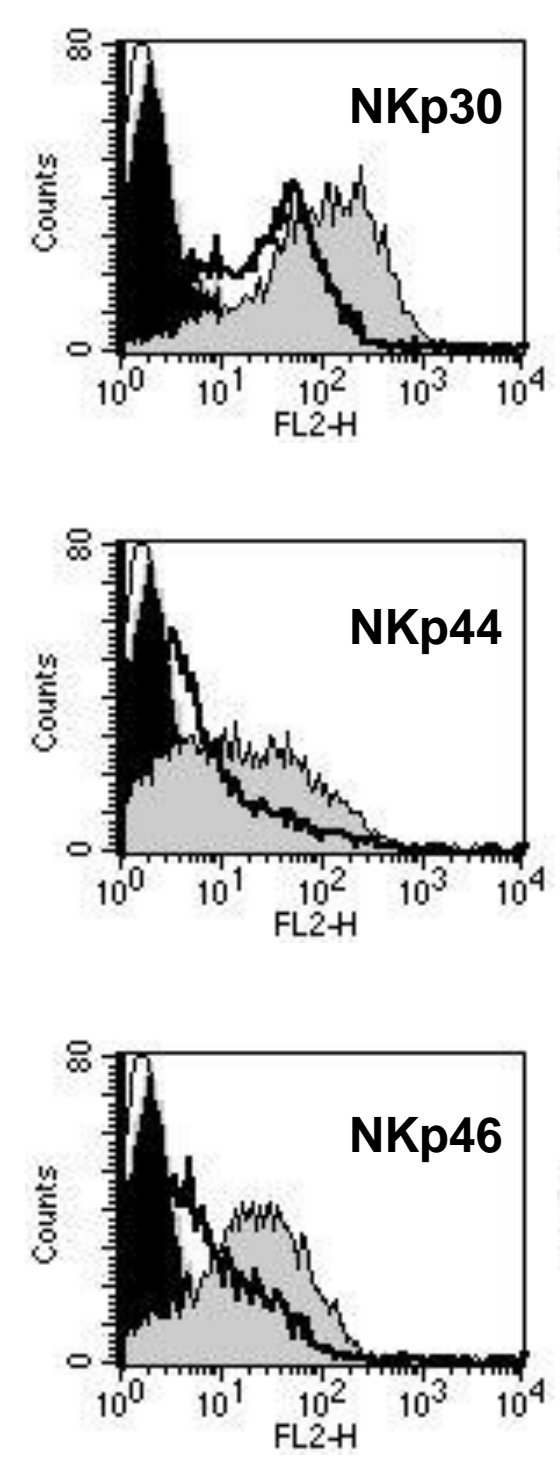
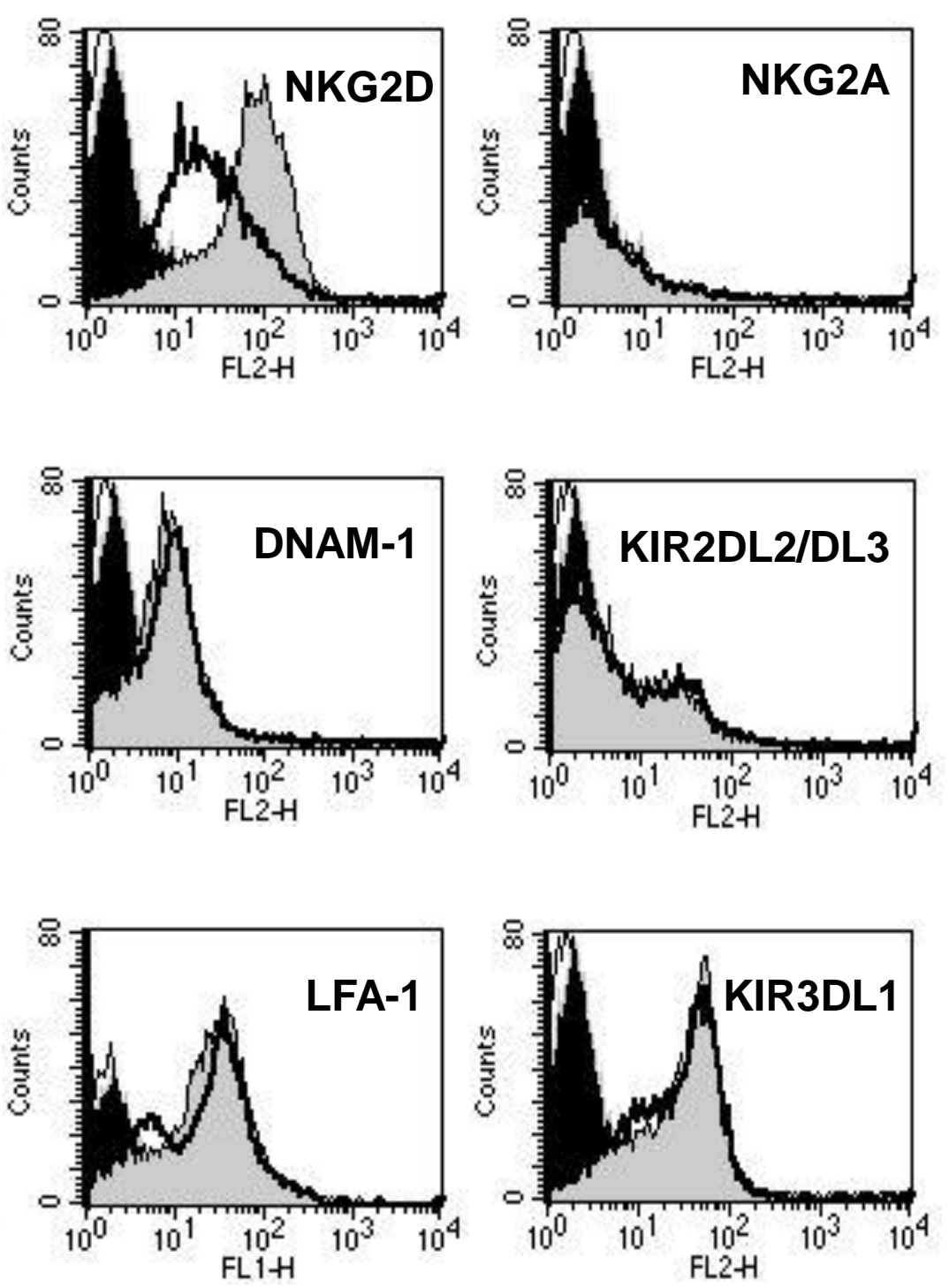

B

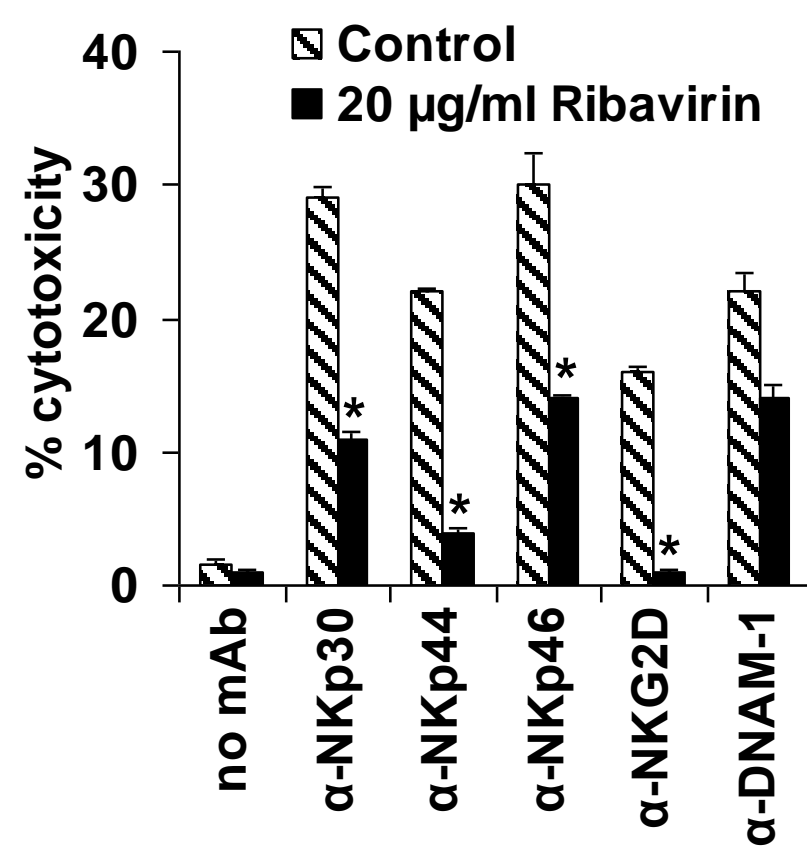




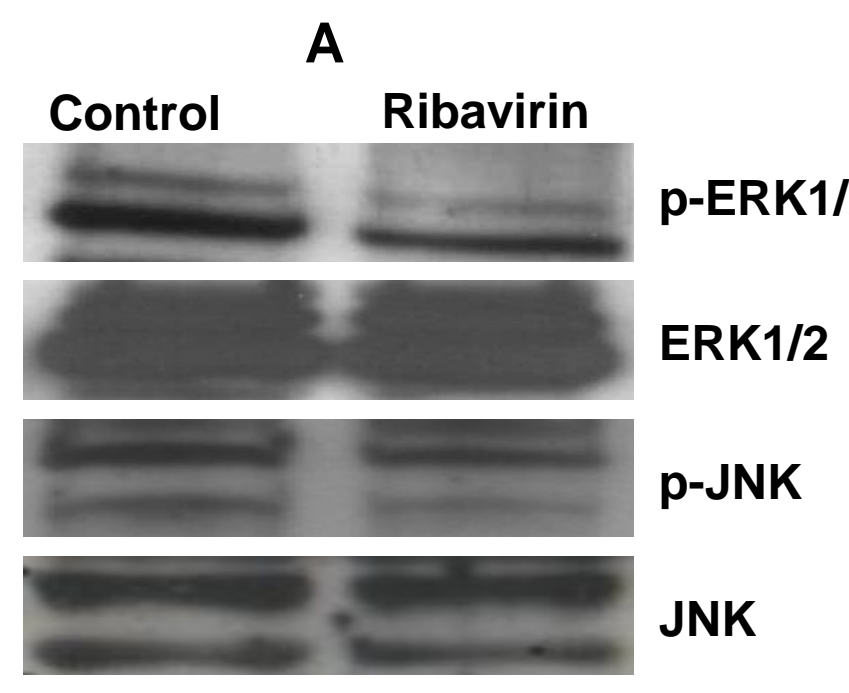

C

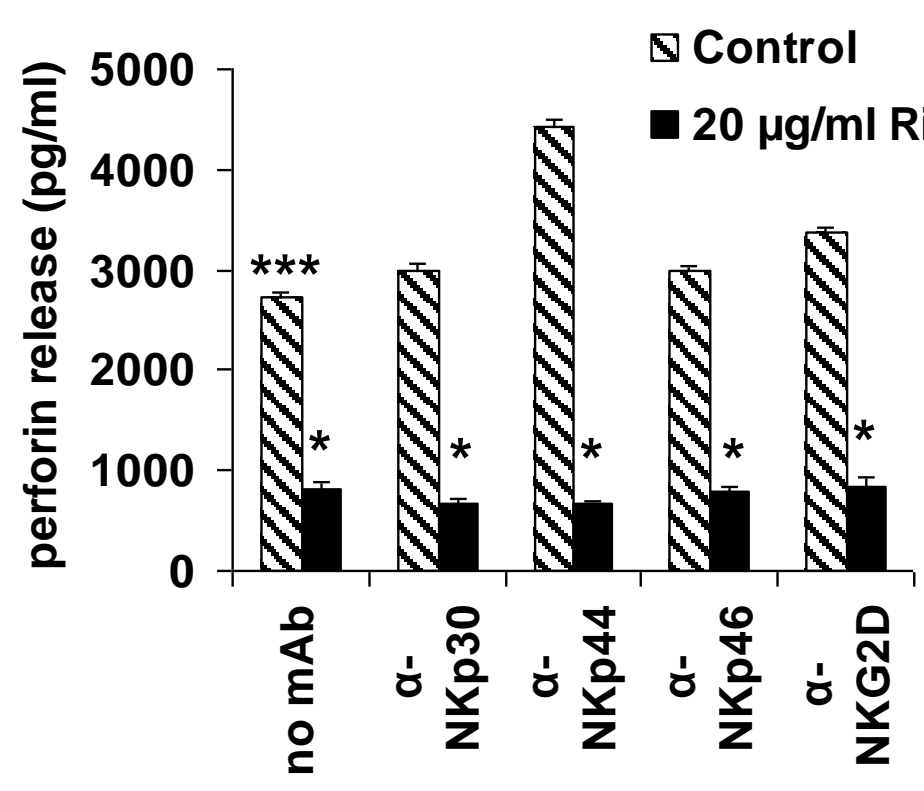

B

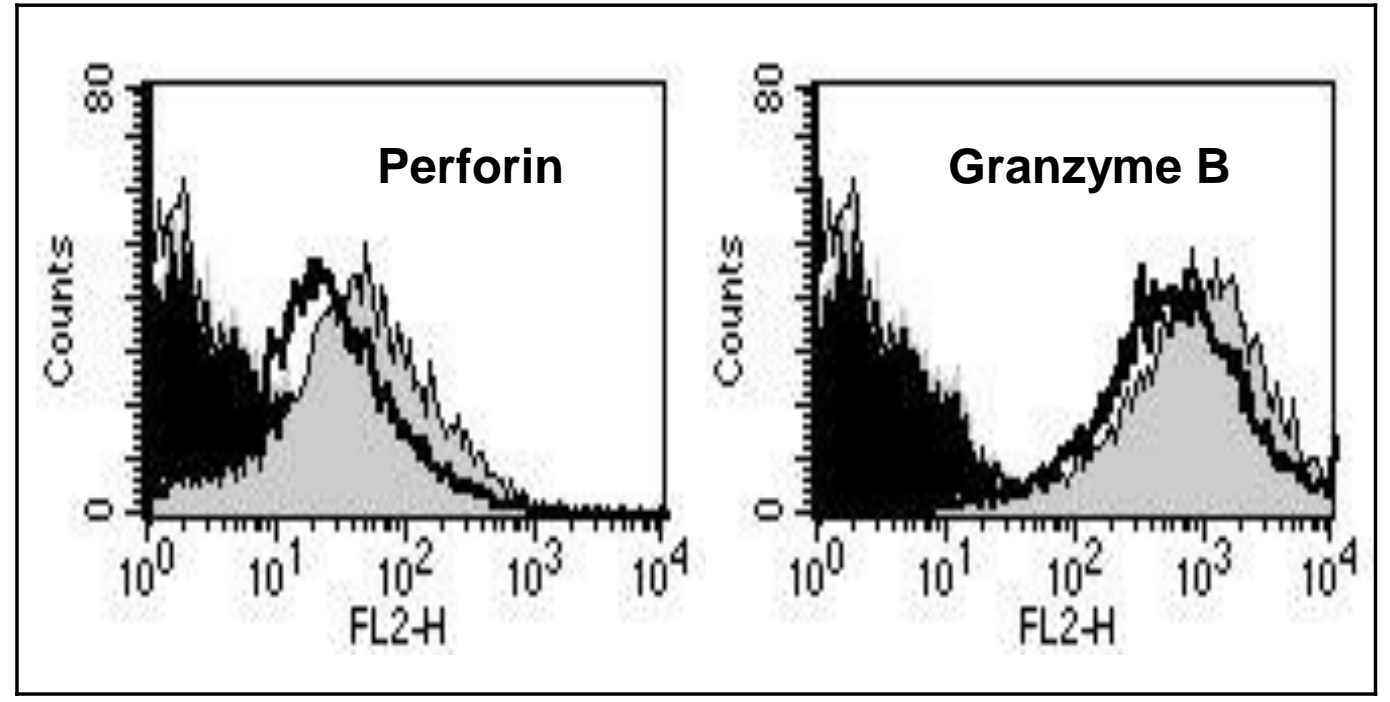

D

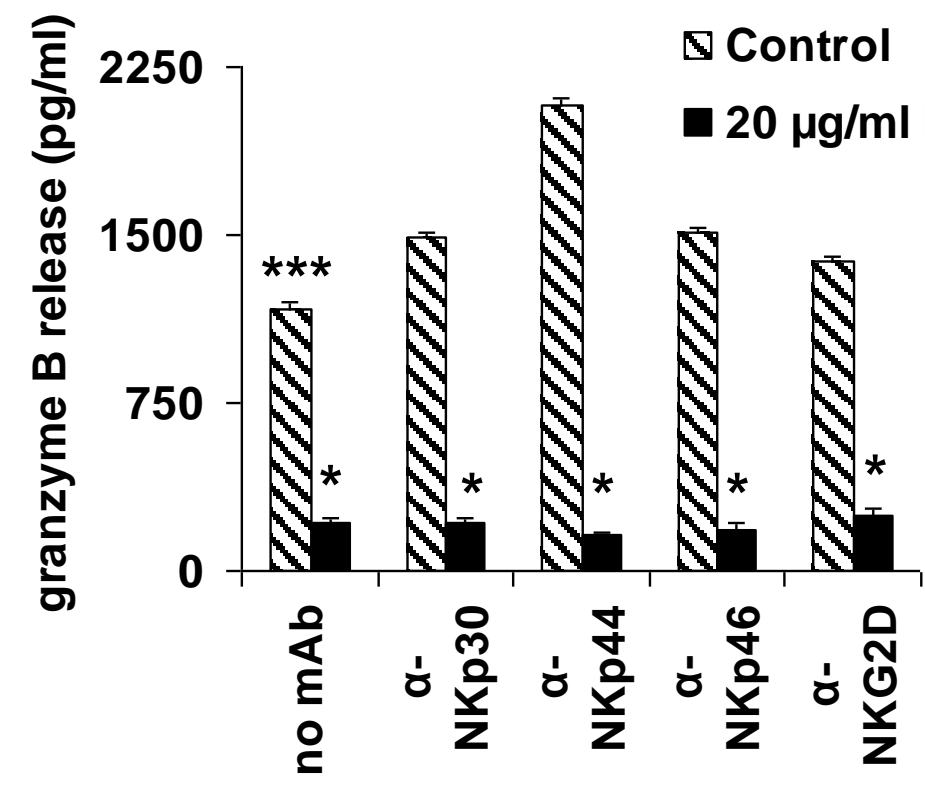



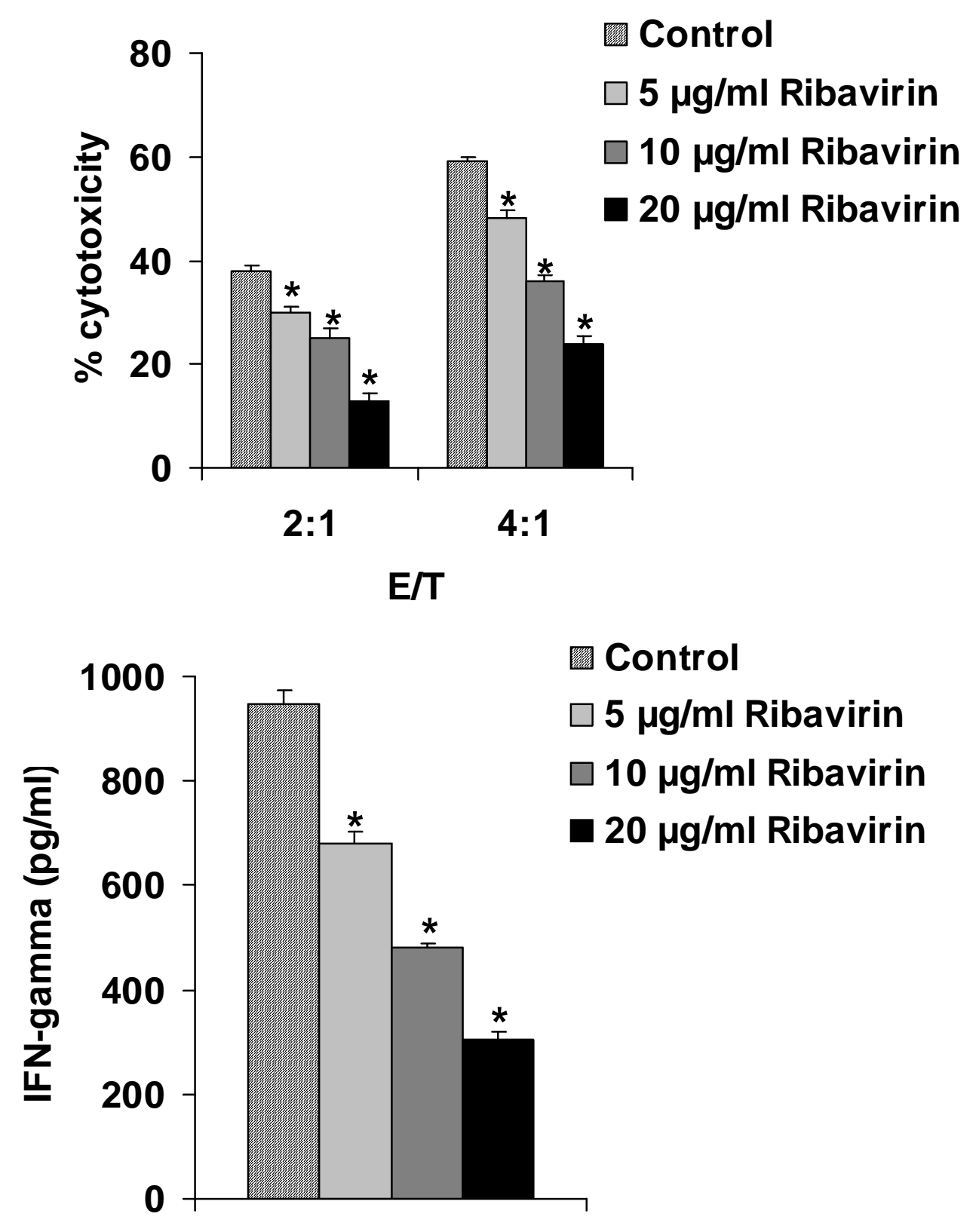

\section{Ribavirin suppresses NK cell function}

